\title{
Sources of discrepancy between aerosol optical depth obtained from AERONET and in-situ aircraft profiles
}

\author{
A. R. Esteve ${ }^{1}$, J. A. Ogren ${ }^{2}$, P. J. Sheridan ${ }^{2}$, E. Andrews ${ }^{2,3}$, B. N. Holben ${ }^{4}$, and M. P. Utrillas ${ }^{1}$ \\ ${ }^{1}$ Department of Earth Physics and Thermodynamics, University of Valencia, Valencia, Spain \\ ${ }^{2}$ Earth System Research Laboratory, National Oceanic and Atmospheric Administration, Boulder, Colorado, USA \\ ${ }^{3}$ Cooperative Institute for Research in Environmental Sciences, University of Colorado, Boulder, Colorado, USA \\ ${ }^{4}$ Goddard Space Flight Center, National Aeronautics and Space Administration, Greenbelt, Maryland, USA
}

Correspondence to: A. R. Esteve (anna.esteve@uv.es)

Received: 29 September 2011 - Published in Atmos. Chem. Phys. Discuss.: 27 October 2011

Revised: 12 March 2012 - Accepted: 14 March 2012 - Published: 27 March 2012

\begin{abstract}
Aerosol optical properties were measured by NOAA's Airborne Aerosol Observatory over Bondville, Illinois, during more than two years using a light aircraft. Measured properties included total light scattering, backscattering, and absorption, while calculated parameters included aerosol optical depth (AOD), Ångström exponent, singlescattering albedo, hemispheric backscatter fraction, asymmetry parameter, and submicrometer mode fraction of scattering. The in-situ aircraft measurements are compared here with AERONET measurements and retrievals of the aerosol optical properties at the same location, although it is difficult to verify the AERONET retrieval algorithm at a site that is not highly polluted. The comparison reveals discrepancies between the aerosol properties retrieved from AERONET and from in-situ aircraft measurements. These discrepancies are smaller for the AOD, while the biggest discrepancies are for the other derived aerosol properties. Possible sources of discrepancy between the AOD measured by AERONET and the one calculated from the in-situ aircraft measurements are investigated. The largest portion of the AOD discrepancy is likely due to an incorrect adjustment to ambient $\mathrm{RH}$ of the scattering coefficient. Another significant part (along with uncertain nephelometer truncation corrections) may come from the possibility that there might be less aerosol below the lowest flight altitude or that the aircraft inlet excludes aerosol particles larger than 5-7 $\mu \mathrm{m}$ diameter.
\end{abstract}

\section{Introduction}

Aerosol particles directly affect the Earth's radiative balance both directly, by scattering and absorbing solar radiation (Charlson et al., 1991, 1992; Kiehl and Briegleb, 1993), and indirectly, through their action as cloud condensation nuclei (CCN) in cloud formation (Kaufman et al., 2005), having been identified as one of the greatest sources of uncertainty in the interpretation of the Earth's climate, on both global and regional scales (Intergovernmental Panel on Climate Change, IPCC, 2007).

The key aerosol optical properties needed to estimate the aerosol radiative forcing of climate are the relative amounts of light scattering and absorption by the aerosol, the fraction of the incident solar radiation that is scattered upward to space by the suspended particles (upscatter fraction), and the aerosol optical depth. The knowledge of these properties along with estimates of solar, atmospheric, and surface properties permits calculation of cloud-free sky direct aerosol radiative forcing effects (Haywood and Shine, 1995).

Aerosol optical properties relevant for direct radiative forcing calculations can be obtained in various ways including in-situ and remote sensing measurements based at the surface, aloft or in space. The globally distributed AErosol RObotic NETwork (AERONET) consists of $\approx 680$ Sun and sky-scanning ground-based automated radiometers and provides column measurements of aerosol optical properties, with up to ten years of observations in some locations (Holben et al., 2001). In-situ measurements of aerosol optical properties and composition are made by numerous groundbased networks around the world (e.g. Delene and Ogren, 2002; VanCuren, 2003). However far fewer in-situ vertical profile measurements of the entire suite of aerosol optical 
properties needed to calculate aerosol radiative forcing have been made (Hegg et al., 1996a, b; Kotchenruther et al., 1999; Sheridan and Ogren, 1999; Öström and Noone, 2000; Russell and Heintzenberg, 2000; Sheridan et al., 2002; Andrews et al., 2004; Osborne and Haywood, 2005; Taubman et al., 2006). Of these in-situ profile measurements most have been made during short-term field campaigns on the order of weeks to months, with the exception of Taubman et al. (2006) and Andrews et al. (2004), who presented in-situ aerosol vertical profile results from the first $2 \mathrm{yr}$ of an $8 \mathrm{yr}$ measurement program over the Southern Great Plains (SGP) cloud and radiation test bed site. Results from Andrews et al. (2004) showed that long-term surface aerosol measurements at SGP statistically capture the column aerosol properties, but may not be as representative of day-to-day variations in the column. The comparison of aerosol optical depth calculated from the vertical profiles with other measurements of AOD made at SGP (i.e. by the Cimel Sun photometer and the multifilter rotating shadowband radiometer, MFRSR) showed fair correlation, but the AOD derived from the column measurements made at SGP was typically about $40 \%$ higher than the AOD calculated from the in-situ vertical profiles, with most of the difference due to an offset of $\approx 0.04$ (at $550 \mathrm{~nm}$ wavelength) between the two approaches.

Aircraft profiling can be a relatively inexpensive method to measure in-situ aerosol properties in the vertical over the long term when using a dedicated light aircraft. In 2006 NOAA's Airborne Aerosol Observatory (AAO) began flying routine profiles over central Illinois using a small aircraft similar to that described in Andrews et al. (2004) but with an enhanced payload. Flights occurred 1-2 times per week with the tandem goals of making climate measurements and verifying satellite observations. AAO measurements relevant to this paper include: vertical profiles of spectral aerosol scattering, $\sigma_{\mathrm{sp}}(\lambda)$, hemispheric backscattering, $\sigma_{\mathrm{bsp}}(\lambda)$, and aerosol absorption, $\sigma_{\mathrm{ap}}(\lambda)$. Unless otherwise noted, values of spectral aerosol optical properties, including AOD, discussed in this paper all refer to a wavelength of $550 \mathrm{~nm}$.

The objective of this paper is to investigate the sources of the observed discrepancies between the AAO's in-situ measurements and the AERONET AOD measurements and almucantar inversion products. This kind of validation has been limited to a few case studies, mostly under conditions of high AOD (Remer et al., 1997; Ramanathan et al., 2001; Bergstrom et al., 2003; Haywood et al., 2003; Reid et al., 2003; Smirnov et al., 2003; Chand et al., 2006; Leahy et al., 2007; Osborne et al., 2008; Schafer et al., 2008; Atkinson et al., 2010; Johnson et al., 2009).

\section{Experimental approach}

\subsection{Airborne aerosol observatory}

The data are obtained by flying an instrumented light aircraft (Cessna T206H) near NOAA's regional monitoring station at Bondville, Illinois, $\left(40^{\circ} 03^{\prime} 12^{\prime \prime} \mathrm{N}, 88^{\circ} 22^{\prime} 19^{\prime \prime} \mathrm{W}, 229 \mathrm{~m}\right.$ above sea level, a.s.l.). This site is an anthropogenically influenced, continental station located at the Illinois State Water Survey's Bondville Environmental and Atmospheric Research site. It is located $6.5 \mathrm{~km}$ south of Bondville, $16 \mathrm{~km}$ west of Champaign-Urbana (population 200 000), and is surrounded by corn and soybean fields. A climatology of aerosol properties observed at Bondville has been reported by KoloutsouVakakis et al. (2001) and Delene and Ogren (2002).

The aerosol system on the AAO aircraft is similar to the system operating on the In-situ Aerosol Profiles (IAP) aircraft, described in detail in Andrews et al. (2004). The airplane is instrumented with an integrating nephelometer (TSI Model 3563, three-wavelength (450, 550 and $700 \mathrm{~nm}$ ), total and hemispheric backscatter capabilities), three single-wavelength nephelometers (Radiance Research Model M903, $\lambda=545 \mathrm{~nm}$ ) downstream of an impactor with a $1 \mu \mathrm{m}$ cut diameter, and a filter-based light absorption photometer (Radiance Research PSAP, three-wavelength, 467, 530 and $660 \mathrm{~nm}$ ). A heater upstream of the instrumentation ensured that measurements were made at low relative humidity (RH) conditions $(\mathrm{RH}<40 \%)$, except for two of the Radiance Research nephelometers that were operated at $65 \%$ and $85 \%$ RH (Covert et al., 1972; Gassó et al., 2000). Particle losses due to ammonium nitrate volatilization in the heated nephelometer were estimated to reduce light scattering by $1-8 \%$ (maximum in winter), based on the measured sample temperature in the nephelometer, the measured loss of ammonium nitrate in the nephelometer as a function of temperature and residence time (Bergin et al., 1997), and the seasonally-averaged fraction of light scattering attributable to ammonium nitrate derived from IMPROVE chemical composition measurements at the surface at Bondville (Hand et al., 2011; J. Hand, personal communication, 2012).

The shrouded inlet on the AAO aircraft is a copy of the inlet used on the NASA DC-8, which was characterized by McNaughton et al. (2007). The DC-8 aerosol inlet system was determined to have an overall sampling efficiency (the product of the efficiency with which particles enter the inlet and the passing efficiency of the sample tubing between the inlet and the instruments) of $50 \%\left(D_{50}\right)$ for particles of $5 \mu \mathrm{m}$ aerodynamic diameter, and was largely controlled by the sampling efficiency of the shrouded inlet, which can be used as the basis for estimating the overall efficiency of the AAO inlet system. The DC- 8 tests were done at an airspeed of $100 \mathrm{~m} \mathrm{~s}^{-1}$, twice as fast as the sampling speed of the AAO aircraft. Assuming that inertial effects control the sampling efficiency of the shrouded inlet, the value of $D_{50}$ should scale 
as the inverse square root of airspeed, yielding a $D_{50}$ of $7 \mu \mathrm{m}$ at the AAO airspeed of $50 \mathrm{~m} \mathrm{~s}^{-1}$. At this size, losses in the downstream tubing are calculated to be only $5 \%$, suggesting that the effective $D_{50}$ of the overall AAO inlet system is close to $7 \mu \mathrm{m}$. A $D_{50}$ for this inlet and air speed of $7 \mu \mathrm{m}$ diameter however implies that some fraction of particles smaller than $7 \mu \mathrm{m}$ are also excluded from or removed in the inlet. Based on scaling the results of the McNaughton et al. (2007) study to our air speed, it is reasonable to conclude that there would be minor losses of particles in the 5-7 $\mu \mathrm{m}$ diameter range in our inlet system and that particles smaller than $\sim 5 \mu \mathrm{m}$ diameter efficiently pass the inlet at 95-100\% efficiency.

The aircraft flew 286 vertical profiles between June 2006 and October 2008. The flights were made 1-2 times each week, randomizing the day of week and the time of day but limited to daylight hours only. The profiles were flown $15 \mathrm{~km}$ northwest of the Bondville site, due to flight safety restrictions resulting from the proximity of the Bondville site $(8 \mathrm{~km})$ to the Champaign Willard Airport. For each profile flight, the Cessna flew 10 level legs at altitudes of $457,610,914,1219,1524,1829,2438,3048,3658$, and $4572 \mathrm{~m}$ a.s.l. (these altitudes correspond to flight altitudes of 1500, 2000, 3000, 4000, 5000, 6000, 8000, 10000,12000 , and 15000 feet a.s.l.). The plane spent approximately $10 \mathrm{~min}$ at the five highest levels and then $5 \mathrm{~min}$ at each of the five lower levels. In addition to the 10 stair step profile levels, the plane flew an additional level leg at $457 \mathrm{~m}$ a.s.l. directly over the surface measurement site so that the surface and lowest flight level leg measurements could be directly compared.

Measured aerosol optical properties include light absorption $\left(\sigma_{\mathrm{ap}}\right)$, light scattering $\left(\sigma_{\mathrm{sp}}\right)$ and hemispheric backscattering $\left(\sigma_{\mathrm{bsp}}\right)$ coefficients at three wavelengths for $D_{\mathrm{p}}<7 \mu \mathrm{m}$, and light scattering $\left(\sigma_{\mathrm{sp}}\right)$ coefficient at one wavelength for $D_{\mathrm{p}}<1 \mu \mathrm{m}$. From $\sigma_{\mathrm{ap}}$ and $\sigma_{\mathrm{sp}}$ the extinction coefficient $\sigma_{\text {ext }}=\sigma_{\text {ap }}+\sigma_{\text {sp }}$ can be calculated. Several climatically important aerosol optical parameters also can be calculated, including: single scattering albedo $\varpi_{\mathrm{o}}=\sigma_{\mathrm{sp}} /\left(\sigma_{\mathrm{sp}}+\sigma_{\mathrm{ap}}\right)$; the asymmetry parameter, estimated with the empirical relationship $g=-7.1439 b^{3}+7.4644 b^{2}-3.9636 b+0.9893$, where $b$ is the hemispheric backscatter fraction $\left(b=\sigma_{\mathrm{bsp}} / \sigma_{\mathrm{sp}}\right)$ (Andrews et al., 2006); and the submicrometer mode scattering fraction, calculated as $\mathrm{FMF}^{\prime}=\sigma_{\mathrm{ext}}^{1 \mu \mathrm{m}} / \sigma_{\mathrm{ext}}^{7 \mu \mathrm{m}}$.

Measurements from the nephelometers were corrected for angular nonidealities using the algorithms described by Anderson and Ogren (1998). Measurements from the PSAP were corrected for sample area, flow rate and nonidealities in the manufacturer's calibration (Bond et al., 1999; Ogren, 2010). Measurement uncertainties for the PSAP and nephelometer have been described in detail elsewhere (Bond et al., 1999; Anderson et al., 1999).

To calculate ambient AOD from the AAO measurements the following procedure was used. First, the flight data are adjusted to ambient temperature, pressure and relative humidity. Scattering coefficients are adjusted to ambient RH using the humidity measured with the RH sensor on the aircraft and the hygroscopic growth equation for the aerosol derived from 12 months of data at Bondville surface site by Koloutsou-Vakakis et al. (2001). No correction is applied to account for the possible contribution of unsampled particles above the highest flight level or larger than the 5$7 \mu \mathrm{m}$ upper cutoff diameter. Moreover, the 10 level legs of each profile flight are assumed to be representative of the air immediately above and below them. The scattering and absorption column averages are calculated from the sum of the products of layer thickness and the aerosol scattering or absorption coefficient in that layer for each of the 10 level legs. The layer thickness $\Delta_{i}$ is defined as the distance from the midpoint between the current level $\ell_{i}$ and the level below up to the midpoint between the current level and the level above $\left(\Delta_{i}=\left[\left(\ell_{i+1}-\ell_{i}\right) / 2\right]+\left[\left(\ell_{i}-\ell_{i-1}\right) / 2\right]\right)$. Later, the wavelength of the absorption coefficient is adjusted to $550 \mathrm{~nm}$ by power law interpolation. Finally, the column average scattering coefficient is added to the column average absorption coefficient to determine the ambient AOD at $550 \mathrm{~nm}$ for the profile. The ambient column average intensive parameters (Ångström exponent, $\varpi_{\mathrm{o}}, g, b$ ) are calculated from the column average absorption, scattering, and hemispheric backscattering coefficients.

\subsection{AERONET sun photometer}

AERONET sun photometer measurements are also made at the Bondville site. For the comparison of aerosol optical properties, the "level 2.0" almucantar inversion products for 2006-2008 were downloaded from the AERONET website (http://aeronet.gsfc.nasa.gov). The almucantar inversion products include, among other things, column-average single scattering albedo, asymmetry parameter, phase function (which allows the calculation of the hemispheric backscatter fraction), and Fine Mode Fraction (FMF) (Dubovik and King, 2000; O'Neill et al., 2001). AERONET data were matched with AAO data using the criteria that the single AERONET measurement to be used in the comparison was within $+/-2 \mathrm{~h}$ of the end of the corresponding AAO flight. For those cases where there was more than one AERONET measurement within that time period, the closest to the end of the AAO flight was the one used in the comparison.

The aerosol properties obtained from AERONET differ in wavelength, altitude range covered, humidity conditions and particle size cut from those observed using the in-situ instruments on the aircraft. Nonetheless, by adjusting the in-situ measurements to ambient conditions, adjusting the wavelength of the AERONET measurements to $550 \mathrm{~nm}$ by power law interpolation, and integrating over the column we can quantitatively compare the two sets of measurements. In the following discussion, all observations are adjusted to a wavelength of $550 \mathrm{~nm}$, unless otherwise noted. 


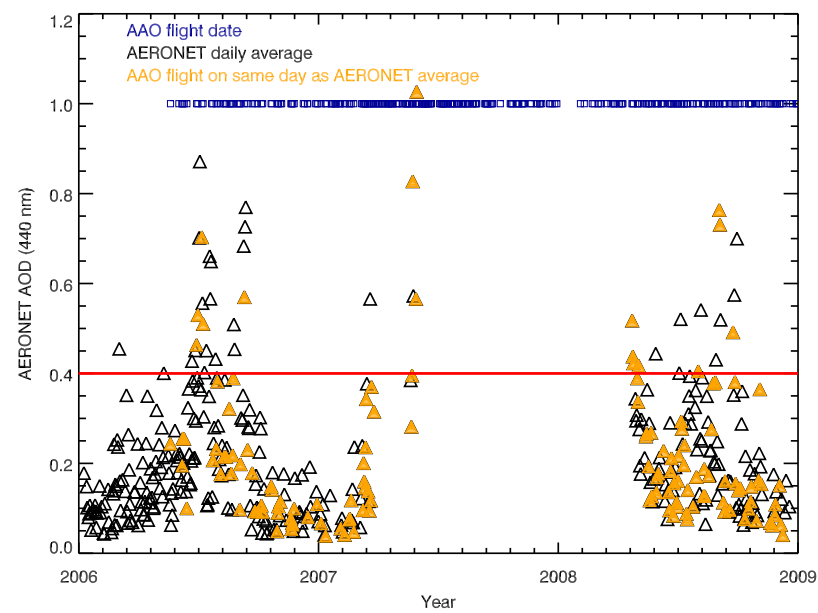

Fig. 1. Daily average of the AAO aircraft calculated aerosol optical depth and of the AERONET optical depth (at $440 \mathrm{~nm}$ ) during the study period, and indicators of the days when AAO data are available.

\section{Results}

A summary of the AERONET AOD observations during the study period is shown in Fig. 1, along with indicators of the days when AAO data are available. Figure 2 shows the comparison of the AOD measured by the AERONET sun photometer with that calculated from the AAO aircraft measurements for ambient conditions of temperature, pressure, and relative humidity. Only complete flights, i.e. flights with valid $\sigma_{\text {ap }}$ and $\sigma_{\text {sp }}$ data for all ten levels were used in this comparison. A total of 157 flights met these criteria. The comparison shows good correlation for both fits used $\left(R^{2} \approx 0.80\right.$ for the standard linear regression not forced through zero and $R^{2} \approx 0.72$ when the line is forced through zero), although the AERONET AOD values are higher than the calculated AAO AOD by nearly a factor of 1.5 on average, based on the slope of the line forced through zero. Moreover, the standard regression line had a significant offset of $\approx 0.05$, similar to the offset observed by Andrews et al. (2004) over Oklahoma. Other studies have also observed that aerosol optical depths measured by remote sensing and in-situ instrumentation are well correlated, and that AOD retrieved from remote sensing measurements are typically higher than the AOD calculated from in-situ measurements (e.g. Schmid et al., 2000, 2009; Hartley et al., 2000; Sheridan et al., 2002; Andrews et al., 2004).

Figure 3 shows the comparison of the Ångström exponent calculated from the AERONET measurements with that calculated from the AAO aircraft measurements for ambient conditions of temperature, pressure, and relative humidity. The wavelength of the AERONET retrievals has been adjusted to $550-700 \mathrm{~nm}$ by power law interpolation. The data are poorly correlated $\left(R^{2} \approx 0.40\right.$ for both types of linear

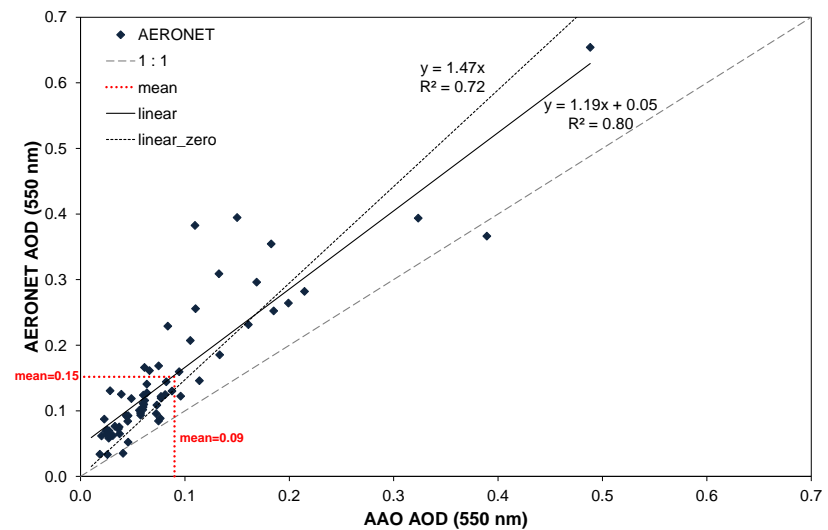

Fig. 2. Comparison of AAO aircraft calculated aerosol optical depth with AERONET optical depth (adjusted to $550 \mathrm{~nm}$ ).

regression), with the AERONET column-average Ångström exponent being lower than that calculated using the AAO measurements. Because Ångström exponent is inversely proportional to particle size, one possible reason for this discrepancy is the differences in the size of aerosols detected by each measurement technique.

The comparison of the ambient, column-average, single scattering albedo yielded only a single point (out of 157 candidate flights) that met the AERONET "level 2.0" inversion criteria. The single comparison point was 0.93 for AAO vs. 0.91 for AERONET (at $550 \mathrm{~nm}$ wavelength). The low percentage of "level 2.0" retrievals points out the difficulty of validating the AERONET retrievals in regions that are not highly polluted, as the "level 2.0" product requires AOD to be greater than 0.4 at $440 \mathrm{~nm}$ wavelength (Dubovik et al., 2000), a value that is rarely observed at Bondville (see the horizontal line in Fig. 1). The AERONET "level 2.0" screening includes other criteria in addition to AOD $>0.4$, which explains the points in Fig. 1 above the horizontal line that did not yield single-scattering albedo retrievals. If we included in our comparison the highly uncertain, low reliability AERONET "level 1.5" single scattering albedo data the number of points would increase to 30 , but we would observe that the values for AERONET and AAO are very poorly correlated $\left(R^{2} \approx 0.23\right.$ for the standard linear regression).

Figure 4 shows the comparison of the aerosol backscatter fraction and the asymmetry parameter. For these two parameters, AAO has a wider range of values than AERONET. The high AAO values of the backscatter fraction $(b>0.13)$ were obtained on relatively clean days $(\mathrm{AOD} \approx 0.07)$, i.e. days when the signal/noise ratio of the nephelometer data was low, and thus less reliable. These variables are closely related to each other and, like the Ångström exponent, are indicators of the particle size. As with the Angström exponent comparison, these plots suggest that the AERONET measurement may include more large particles than does AAO. 


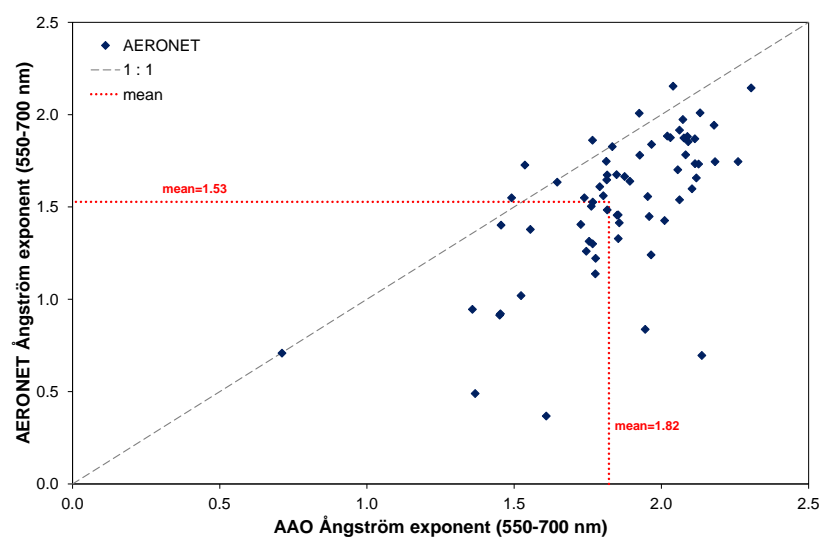

Fig. 3. Comparison of AAO aircraft calculated Ångström exponent with AERONET Ångström exponent (adjusted to 550-700 nm).

The spectral AOD from AERONET measurements is used to calculate the Fine Mode Fraction (FMF) of aerosol optical depth (O'Neill et al., 2001). Figure 5 shows a comparison of the FMF calculated from the AERONET measurements with the submicrometer mode scattering fraction $\left(\mathrm{FMF}^{\prime}\right)$ calculated from the AAO scattering measurements. Although AERONET just provides "level 1.5" FMF, for our comparison we have only used those FMF data with "level 2.0" AOD data. AERONET calculates the FMF at $500 \mathrm{~nm}$, while AAO's submicrometer Mode Fraction $\left(\mathrm{FMF}^{\prime}\right)$ is calculated at $545 \mathrm{~nm}$. Surface data from Bondville show that the average $\mathrm{FMF}^{\prime}$ at $500 \mathrm{~nm}$ is 0.84 , compared to an average value of 0.82 at $550 \mathrm{~nm}$, so that the bias due to the different wavelengths for FMF and $\mathrm{FMF}^{\prime}$ is minimal. Moreover, $\mathrm{FMF}^{\prime}$ is calculated from scattering only, since the submicrometer absorption coefficient was not measured on the airplane. This difference is minor, however, because scattering accounts for about $90 \%$ of extinction. We can observe that AAO values are slightly higher than the AERONET values, with a narrower range of values. Differences in this comparison may partly be due to the different definition of "Fine Mode": the airplane impactor has an aerodynamic diameter of $1 \mu \mathrm{m}$, corresponding to a geometric diameter of about $0.7 \mu \mathrm{m}$, while the AERONET fine mode is not defined on the basis of a specific particle size, but rather on an optical definition relying on the spectral response of the coarse mode aerosol.

Table 1 summarizes the main results of the comparison of the aerosol properties calculated from AERONET with those calculated from AAO.

\section{Discussion}

The comparisons presented in Figs. 2-5 suggest discrepancies (in some cases quite large) between the two approaches for determining AOD and column average intensive parameters such as single scattering albedo. In this section we focus

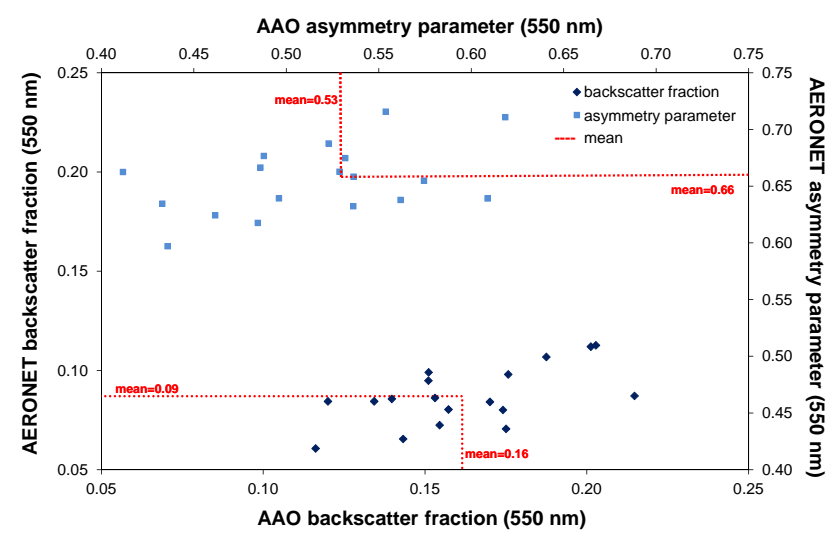

Fig. 4. Comparison of AAO aircraft calculated hemispheric backscatter fraction and asymmetry parameter with AERONET hemispheric backscatter fraction (calculated from the phase function and adjusted to $550 \mathrm{~nm}$ ) and asymmetry parameter (adjusted to $550 \mathrm{~nm})$.

on investigating potential causes of the differences between these two sets of measurements, in particular the differences in AOD. Possible sources of discrepancy between the AOD measured by AERONET and that calculated from the AAO aircraft measurements include:

1. incorrect adjustment of $\sigma_{\mathrm{sp}}$ and $\sigma_{\mathrm{bsp}}$ values to ambient $\mathrm{RH}$ due to choice of hygroscopic growth parameterization or uncertainties in measured $\mathrm{RH}$;

2. aircraft inlet excludes larger aerosol particles, while AERONET sun photometer measures all particles;

3. aerosol layers below, between or above the fixed flight altitudes;

4. incorrect correction of the nephelometer data for angular nonidealities, including truncation effects;

5. incorrect AERONET AOD cloud screening method;

6. incorrect adjustment of the wavelength of the AERONET sun photometer to $550 \mathrm{~nm}$;

7. temporal variability of the aerosol optical properties;

8. bias in the AAO and/or AERONET measurements.

Below we explore the viability of each of these hypotheses.

\subsection{Correction to ambient RH}

A possible cause of the discrepancy between the AOD measured by AERONET and the one calculated from the AAO aircraft measurements is the method used to adjust the AAO measurements made at low RH to ambient RH conditions. As described earlier, the ambient RH sensor on the airplane was used in conjunction with the Koloutsou-Vakakis 
Table 1. Mean values of the AOD, Ångström exponent, single scattering albedo, hemispheric backscatter fraction, asymmetry parameter, and FMF for AAO and AERONET, along with results of least-squares linear regressions and correlation coefficients for the comparison between AERONET and AAO.

\begin{tabular}{lllllll}
\hline & $\begin{array}{l}\text { AAO } \\
\text { mean }\end{array}$ & $\begin{array}{l}\text { AERONET } \\
\text { mean }\end{array}$ & $\begin{array}{l}\text { Standard linear } \\
\text { regression } \\
y=a x+b\end{array}$ & $\begin{array}{l}R^{2} \\
y=a x+b\end{array}$ & $\begin{array}{l}\text { Linear } \\
\text { regression } \\
y=a x\end{array}$ & $\begin{array}{l}R^{2} \\
y=a x\end{array}$ \\
\hline $\mathrm{AOD}$ & 0.09 & 0.15 & $y=1.19 x+0.05$ & 0.80 & $y=1.47 x$ & 0.72 \\
$\mathrm{a}$ & 1.82 & 1.53 & $y=0.92 x-0.18$ & 0.40 & $y=0.82 x$ & 0.40 \\
$\varpi_{\mathrm{O}}$ & $0.93^{\mathrm{b}}$ & $0.91^{\mathrm{b}}$ & - & - & - & - \\
$b$ & 0.16 & 0.09 & $y=0.32 x+0.04$ & 0.35 & $y=0.53 \mathrm{x}$ & 0.18 \\
$g$ & 0.53 & 0.66 & $y=0.24 x+0.53$ & $0.20^{\mathrm{c}}$ & - & - \\
$\mathrm{FMF}$ & 0.79 & 0.76 & $y^{-} 0.69 x+0.18$ & 0.23 & $y=0.89 x$ & 0.21 \\
\hline
\end{tabular}

a $x=$ AAO, $y=$ AERONET.

$\mathrm{b}$ These are not "mean" values, they are the values for the only overlapping "level 2.0" data point from AERONET.

c The standard significance level $(p<0.05)$ is exceeded.

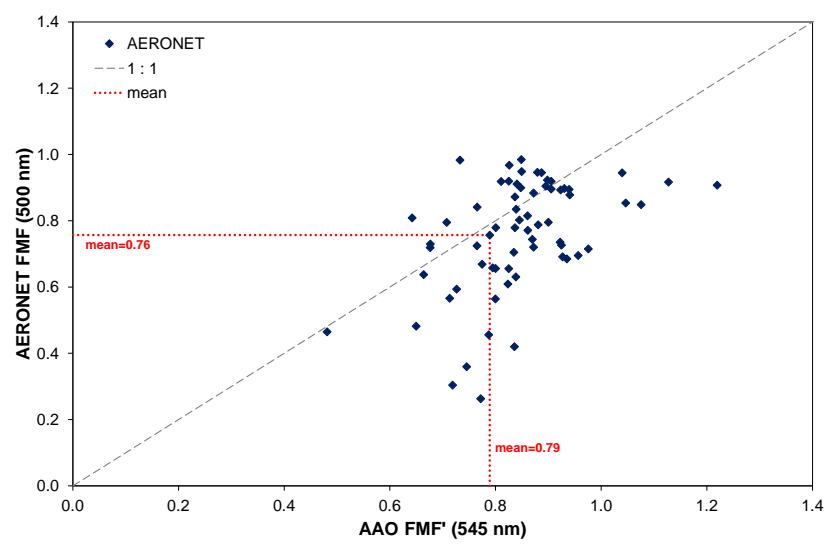

Fig. 5. Comparison of AAO aircraft calculated submicrometer Mode Fraction (at $545 \mathrm{~nm}$ ) with AERONET Fine Mode Fraction (at $500 \mathrm{~nm}$ ).

et al. (2001) equation derived from 12 months of data at the surface site to make this adjustment. Alternative hygroscopic growth adjustment strategies, including a parameterization based on aerosol chemistry and fitting a curve to the AAO humidified nephelometer measurements, which will be explored later, were not considered due to the shorter period of reliable measurements available.

For flights where the $\mathrm{RH}$ of all the flight segments is less than $60 \%$, the adjustment to ambient RH is minimal. Figure 6 shows the comparison of the AOD measured by AERONET with that calculated from the AAO aircraft measurements for this low RH criteria and suggests that the agreement between the AOD measured by AERONET and the one calculated from the AAO aircraft measurements is significantly improved at low RH conditions (although there is still an offset on the order of 0.05). Figure 6 lends support to two hypotheses: (a) unsampled particles or bias in the AERONET AOD measurement contributes a constant AOD of about 0.05 , and (b) there is a problem with the adjustment

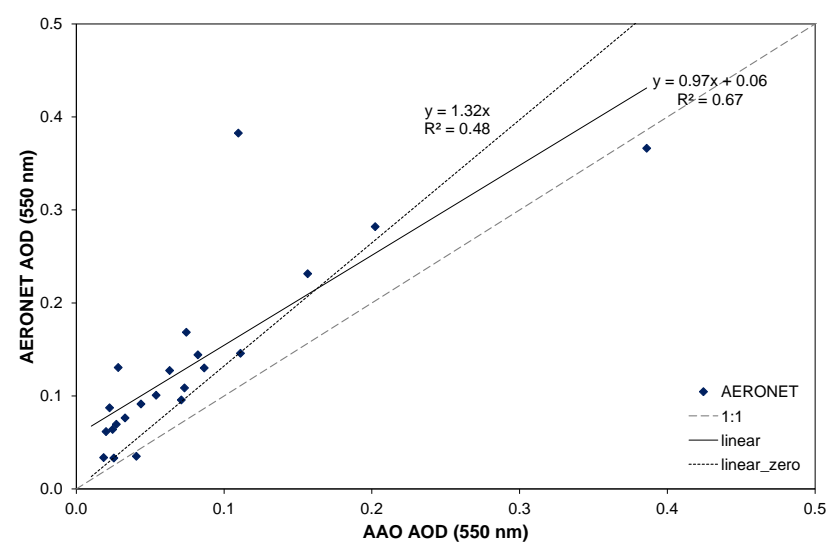

Fig. 6. Comparison of AAO aircraft calculated aerosol optical depth with AERONET optical depth (adjusted to $550 \mathrm{~nm}$ ) for flights that have a $\mathrm{RH}<60 \%$ for all 11 levels.

to ambient $\mathrm{RH}$; we explore the two components of that adjustment (AAO RH measurement and choice of $f(\mathrm{RH})$ parameterization) below.

To discuss the hypothesis of the incorrect $\mathrm{RH}$ measurements on AAO, the $\mathrm{RH}$ data from atmospheric soundings from Lincoln, Illinois, are compared with the AAO ambient RH measurements. Lincoln is located $60 \mathrm{~km}$ west of Bondville, and mesoscale variability of humidity is expected to make the comparison noisy. However, this variability is unlikely to contribute a significant bias to the comparison. Figure 7 shows box-whisker plots of the seasonal vertical profiles of the $\mathrm{RH}$ from the atmospheric soundings corresponding to AAO flights and the median RH from the AAO flights. This plot suggests that the AAO RH sensor tends to read lower than the soundings. Some differences in $\mathrm{RH}$ are expected, however, due to the different sampling protocols: AAO flights avoid clouds while the soundings measure the entire profile. 

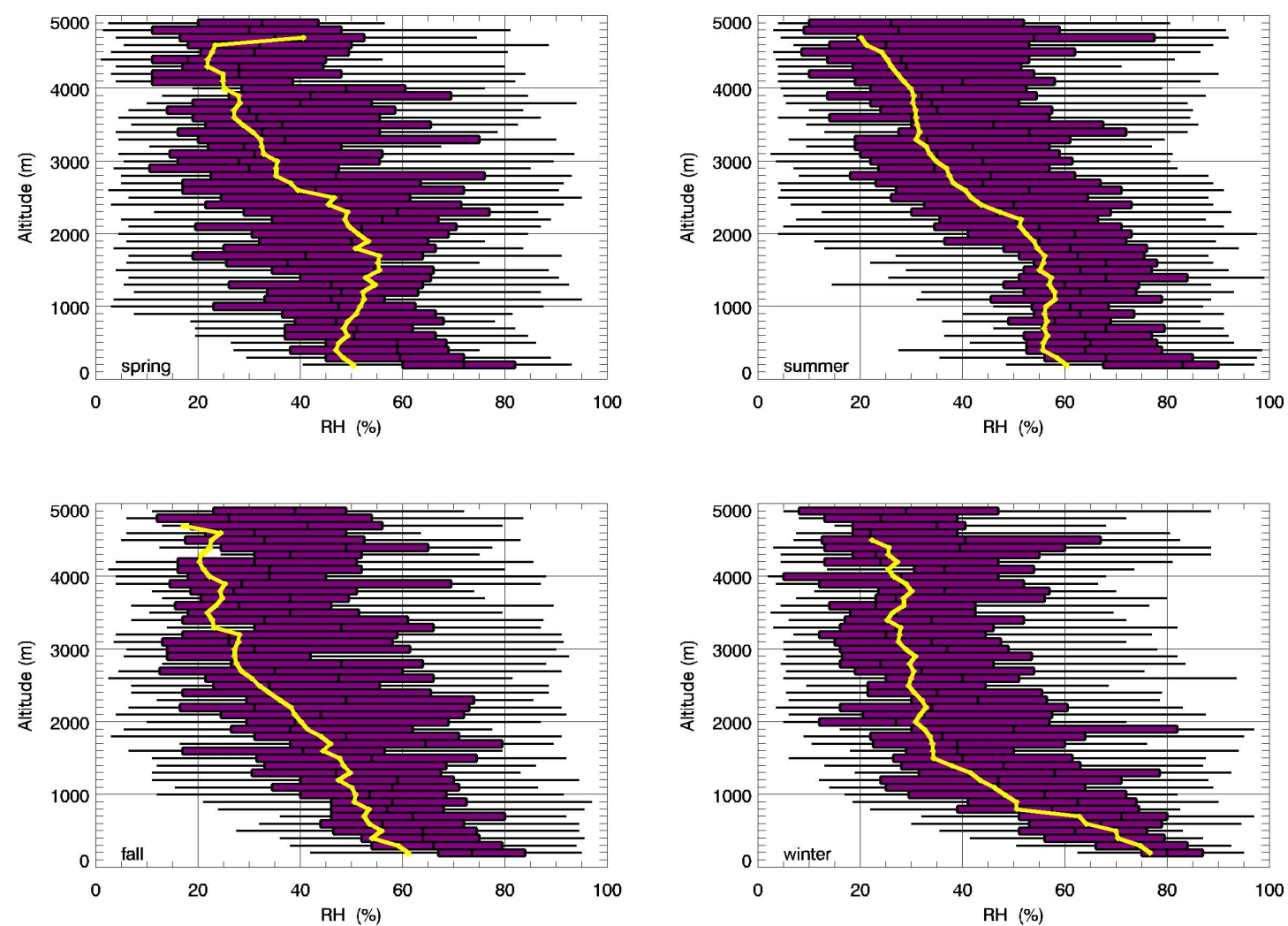

Fig. 7. Seasonal vertical profiles of the RH from the atmospheric soundings at Lincoln, Illinois, corresponding to AAO flights (box-whisker plots) and the median RH from the AAO flights (yellow line).

In order to see how an erroneous reading from the AAO RH sensor might affect the results, the AAO AOD was recalculated using the RH from the atmospheric sounding in place of the RH from the AAO RH sensor. The result shows that the AAO AOD adjusted to the ambient RH from the atmospheric sounding is only $3 \%$ higher than the value derived from the AAO RH sensor, with very high correlation $\left(R^{2}=0.94\right)$. This suggests that, if the discrepancy is related to the humidity adjustment, it is more likely due to an incorrect hygroscopic growth equation than to errors in the ambient RH measurements on AAO.

Next, alternative hygroscopic growth adjustment strategies, including a parameterization based on aerosol chemistry and fitting a curve to the AAO humidified nephelometer measurements, are explored. Quinn et al. (2005) derived a parameterization for the hygroscopic growth factor, $f(\mathrm{RH})$, based on the relative amounts of particulate organic matter $(\mathrm{POM})$ and sulfate $\left(\mathrm{SO}_{4}^{2-}\right)$ in the aerosol. Simultaneous measurements of $\mathrm{POM}$ and $\mathrm{SO}_{4}^{2-}$ are not available from the AAO aircraft, however, they were both measured during limitedduration campaigns as part of the Koloutsou-Vakakis et al. (2001) study of $f(\mathrm{RH})$ at Bondville. For those campaigns, POM and $\mathrm{SO}_{4}^{2-}$ were $22.3 \%$ and $36.6 \%$ of the submicrometer aerosol mass, respectively. Using those values of the
$\mathrm{POM}$ and $\mathrm{SO}_{4}^{2-}$ mass fractions, and a reference $\mathrm{RH}$ of $40 \%$, a value of gamma $\left(\gamma=0.9-0.6 \times\left(\mathrm{POM} /\left(\mathrm{POM}+\mathrm{SO}_{4}^{2-}\right)\right)\right)$ of 0.67 was calculated. An identical gamma value is obtained using the IMPROVE (Interagency Monitoring of PROtected Visual Environments) chemistry measurements made at the Bondville surface site between January 2006 and December 2008, assuming an organic carbon fraction, which is the ratio of organic-mass-to-organic-carbon, of 1.4. A gamma of 0.67 yields an estimated $f(\mathrm{RH})$ (at $82.5 \% \mathrm{RH}$ ) of 2.28 using the Quinn et al. (2005) parameterization compared to the $f(\mathrm{RH})$ value of $1.5(\gamma=0.33)$ derived from the KoloutsouVakakis parameterization for the same $\mathrm{RH}$.

A third gamma value can be derived from the three Radiance Research nephelometers on the AAO aircraft. These nephelometers measured the submicrometer scattering coefficient as a function of $\mathrm{RH}(<40 \%, 65 \%$, and $85 \%)$, but reliable data are only available for a subset (12) of the flights. A median value of gamma of 0.51 is derived by fitting a curve of the form $f(\mathrm{RH})=\left[\left(1-\mathrm{RH}_{\mathrm{wet}}\right) /\left(1-\mathrm{RH}_{\mathrm{dry}}\right)\right]^{-\gamma}$ to the humidified nephelometer measurements on AAO. This value of gamma results in an estimated $f(\mathrm{RH})($ at $82.5 \% \mathrm{RH})$ of 1.87 , intermediate to the values derived from the chemical composition and Koloutsou-Vakasis approaches. 


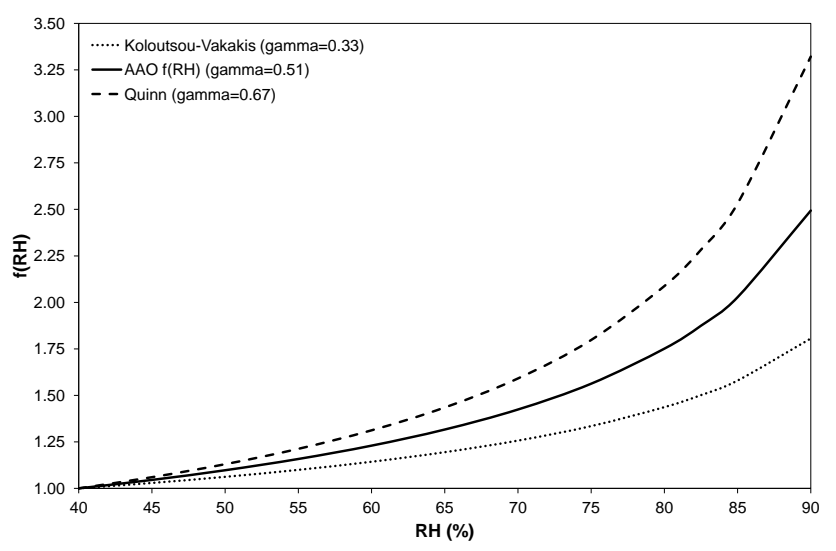

Fig. 8. Hygroscopic growth factor for light scattering, $f(\mathrm{RH})$, for Koloutsou-Vakakis et al. (2001) parameterization, Quinn et al. (2005) parameterization, and the limited AAO $f(\mathrm{RH})$ analysis.

Figure 8 shows the scattering hygroscopic growth factor, $f(\mathrm{RH})$, for both gamma parameterizations and the Koloutsou-Vakakis $f(\mathrm{RH})$ analysis. We note that the Koloutsou-Vakakis et al. (2001) parameterization used to adjust the AAO data to ambient RH is consistent with the results obtained for the FAAM BAe146 aircraft over the UK for the period 2006-2007 (Haywood et al., 2008). It is beyond the scope of this work to determine what causes the differences in these three parameterizations so we will just utilize them to show the range of possibilities.

As a test of the sensitivity of the calculated AOD to the choice of $f(\mathrm{RH})$ parameterization, the calculations were repeated using the Quinn et al. (2005) parameterization, with a value of gamma of 0.67 , and the AAO $f(\mathrm{RH})$ analysis, with a value of gamma of 0.51 . Figure 9 shows the comparison of the AAO aircraft calculated AOD adjusted to ambient RH using Quinn et al. (2005) parameterization $(\gamma=0.67)$ (Fig. 10a) and AAO $f(\mathrm{RH})$ analysis $(\gamma=0.51)$ (Fig. 10b) with the AAO AOD adjusted to ambient RH using Koloutsou-Vakakis et al. (2001) parameterization $(\gamma=0.33)$. Using these alternative $f(\mathrm{RH})$ adjustments results in enhancements of $9.9 \pm 0.4$ percent $(\gamma=0.51)$ or $17.8 \pm 0.8$ percent $(\gamma=0.67)$ in calculated AOD compared to that calculated using the KoloutsouVakakis equation $(\gamma=0.33)$. This enhancement is in the right direction but is not enough to explain fully the observed discrepancies between the AOD measured by AERONET and the one calculated from the AAO aircraft measurements.

Table 2 shows the linear regressions and correlation coefficients for the comparison between AERONET and AAO for the three different adjustments to ambient $\mathrm{RH}$ and the two different measurements of ambient $\mathrm{RH}$. The comparison shows fair correlation for all cases $\left(R^{2}\right.$ between 0.78 and 0.80 for the standard linear regression), although the aircraft AOD tends to have a consistent offset for all cases of $\approx 0.05$. The results in Table 2 suggest that the choice of RH measurement has a lower effect on AOD than the choice of hygroscopic
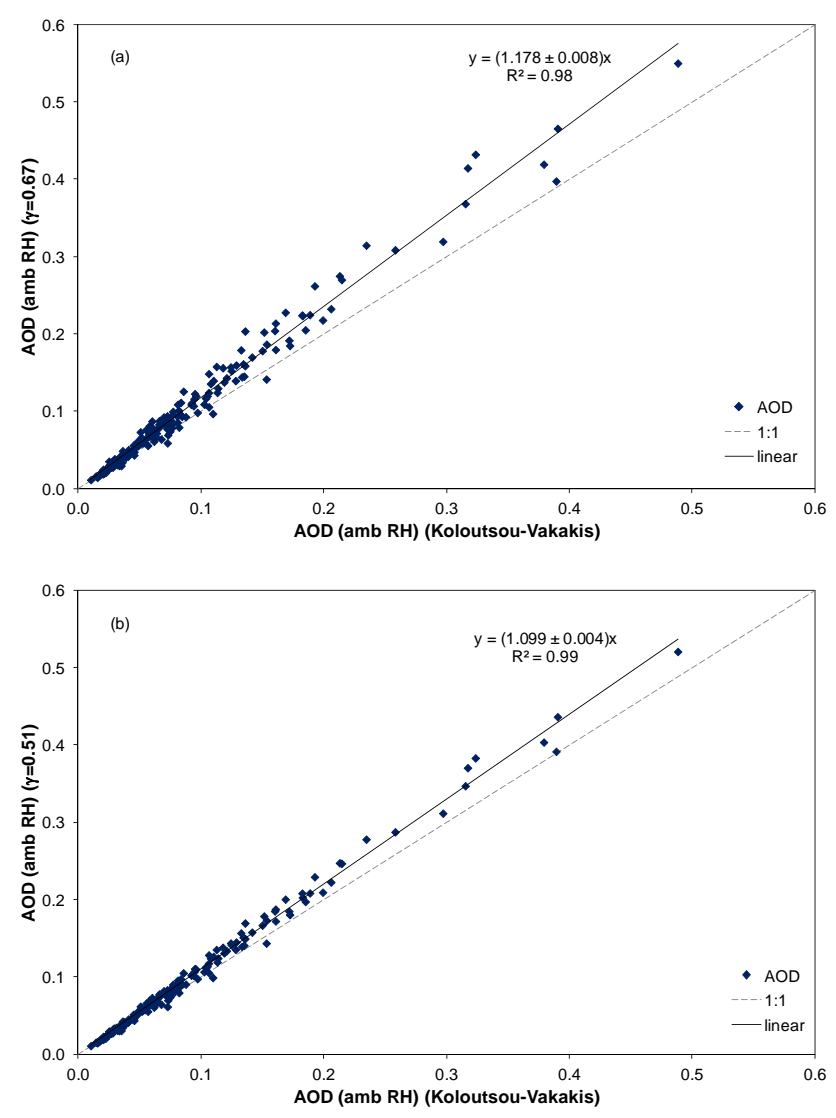

Fig. 9. Comparison of AAO aircraft calculated AOD adjusted to ambient $\mathrm{RH}$ using (a) Quinn et al. (2005) parameterization $(\gamma=0.67)$ and (b) AAO $f(\mathrm{RH})$ analysis $(\gamma=0.51)$ with AAO AOD adjusted to ambient RH using Koloutsou-Vakakis et al. (2001) parameterization $(\gamma=0.33)$ (at $550 \mathrm{~nm})$.

growth parameterization. Using the highest gamma value results in the best comparison between AAO and AERONET AOD, but there is still a significant discrepancy. The best agreement between AAO and AERONET AOD would require a value of $\gamma=0.73$, which would yield a regression slope of 0.99 and $R^{2}=0.80$; however, the intercept of 0.05 would remain even in this case.

To see how the different adjustments and measurements of ambient RH affect the contribution of humidified aerosol layers to the AOD calculated from the AAO aircraft measurements, the cumulative fraction of the aerosol optical thickness for each flight level adjusted to different ambient RH with different parameterizations has been analyzed against the RH (Fig. 10). The first observation is that half the "dry" AOD, i.e. the AOD not adjusted to ambient RH, comes from layers with RH above $63 \%$. When the aerosol is humidified using the AAO RH sensor measurement and the KoloutsouVakakis et al. (2001) parameterization $(\gamma=0.33)$, that value shifts to $66 \%$, and using the Quinn et al. (2005) parameterization $(\gamma=0.67)$ it shifts to $70 \%$. A value of $60 \%$ 
Table 2. Linear regressions and correlation coefficients for the comparison between AERONET and AAO using different measurements of ambient RH and different adjustments to ambient RH.

\begin{tabular}{lll}
\hline & $\begin{array}{l}\text { Linear regression* } \\
y=a x+b\end{array}$ & $\begin{array}{l}\text { Linear regression* } \\
y=a x\end{array}$ \\
\hline AAO RH/Koloutsou-Vakakis & $y=(1.19 \pm 0.07) x+(0.047 \pm 0.009) R^{2}=0.80$ & $y=(1.47 \pm 0.06) x R^{2}=0.72$ \\
Sounding RH/Koloutsou-Vakakis & $y=(1.21 \pm 0.08) x+(0.042 \pm 0.009) R^{2}=0.79$ & $y=(1.47 \pm 0.06) x R^{2}=0.73$ \\
AAO RH/ $\gamma=0.67$ & $y=(1.03 \pm 0.06) x+(0.047 \pm 0.009) R^{2}=0.80$ & $y=(1.27 \pm 0.05) x R^{2}=0.72$ \\
Sounding RH/ $\gamma=0.67$ & $y=(1.03 \pm 0.09) x+(0.047 \pm 0.015) R^{2}=0.79$ & $y=(1.23 \pm 0.07) x R^{2}=0.73$ \\
AAO RH/AAO $f(\mathrm{RH})(\gamma=0.51)$ & $y=(1.10 \pm 0.07) x+(0.046 \pm 0.009) R^{2}=0.80$ & $y=(1.36 \pm 0.06) x R^{2}=0.72$ \\
Ssounding RH/AAO $f(\mathrm{RH})(\gamma=0.51)$ & $y=(1.11 \pm 0.09) x+(0.046 \pm 0.015) R^{2}=0.80$ & $y=(1.32 \pm 0.07) x R^{2}=0.74$ \\
\hline
\end{tabular}

$* x=\mathrm{AAO}, y=$ AERONET .

comes from using the ambient $\mathrm{RH}$ measured by the atmospheric sounding and the Quinn et al. (2005) parameterization $(\gamma=0.67)$. Therefore, using different adjustments to ambient RH makes a bigger difference in the AOD than using different measurements of ambient $\mathrm{RH}$.

In summary, it has been shown that the more important changes in the results occur when using different hygroscopicity parameterizations (Koloutsou-Vakakis et al., 2001, or Quinn et al., 2005; $\gamma=0.67)$ to adjust the values of $\sigma_{\text {sp }}$ and $\sigma_{\text {bsp }}$ to ambient RH. To illustrate this, Table 3 shows the important effect that the different hygroscopicity parameterizations have on the comparison between the aerosol optical properties measured and retrieved by AERONET and those calculated from the AAO aircraft measurements. We can observe how the agreement between the AERONET AOD and that calculated from the AAO aircraft measurements improves when using a greater value of gamma, although the significant differences observed for the comparison of the derived aerosol properties stay the same.

\subsection{AAO inlet excludes larger aerosol particles}

The hypothesis that larger aerosol particles were excluded by the aircraft inlet is consistent with the lower AOD values and higher Ångström exponent and FMF values on AAO aircraft (e.g. Figs. 3 and 5). Two previous observations counter this hypothesis: (1) at the Bondville surface site, only $15 \%$ of the scattering is due to coarse mode particles (Delene and Ogren, 2002); and (2) AOD calculated from the in-situ vertical profile measurements made at the Southern Great Plains (SGP) cloud and radiation test bed site during the Aerosol Lidar Validation Experiment (ALIVE) using an identical inlet as on AAO agreed with the sun photometer measurements (Schmid et al., 2009). Using the AERONET and AAO data from this study we compare the Fine AOD retrieved by AERONET with the submicrometer AOD calculated from the AAO aircraft measurements (Fig. 11). AERONET Fine AOD has been calculated at $500 \mathrm{~nm}$, while the AAO submicrometer AOD is calculated at $545 \mathrm{~nm}$. The comparison shows fair correlation $\left(R^{2} \approx 0.86\right)$, with an offset of $\approx 0.02$

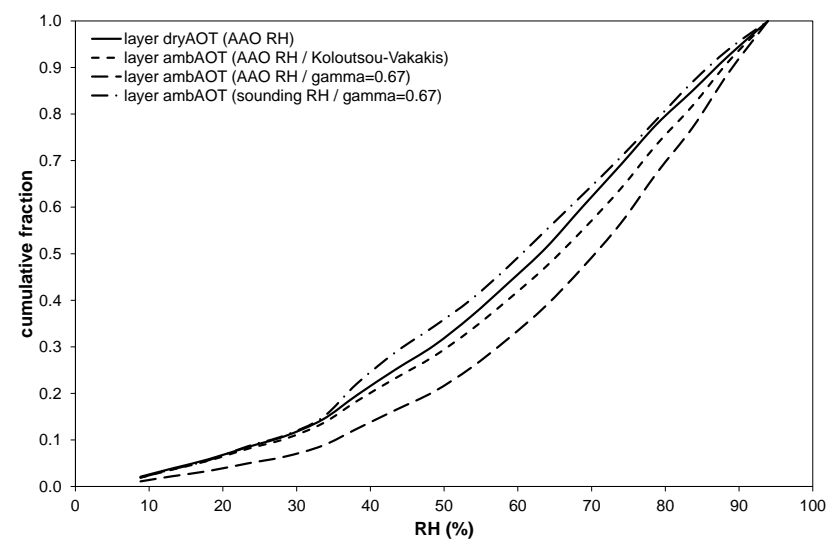

Fig. 10. Cumulative fraction of the AAO aerosol optical thickness for each flight level adjusted to low RH measured by the AAO RH sensor, the AAO aerosol optical thickness for each flight level adjusted to the ambient RH measured by the AAO RH sensor using both Koloutsou-Vakakis et al. (2001) $(\gamma=0.33)$ and Quinn et al. $(2005)(\gamma=0.67)$ parameterizations, and the AAO aerosol optical thickness for each flight level adjusted to the ambient RH measured by the atmospheric sounding using Quinn et al. (2005) parameterization $(\gamma=0.67)$.

for the aircraft submicrometer AOD. Moreover, AERONET Fine AOD values are higher than the calculated AAO submicrometer AOD, showing that the AOD discrepancy exists even for fine mode particles.

One way to gain insight on whether the inlet is excluding large particles is the direct comparison of AAO and surface scattering measurements. Figure 12 shows the comparison of the AAO averaged scattering coefficients from the lowest flight level over Bondville with the surface scattering data over the profile duration. The two lines are linear fits; one being forced through zero. The comparison shows that AAO is measuring 10-20\% less scattering than that measured on the ground. One explanation for this could be that the AAO inlet is excluding some supermicrometer particles. Another possibility, which will be analyzed later, is that the particles 
Table 3. Slopes of the linear regressions forced through zero for the comparison between AERONET and AAO using different hygroscopicity parameterizations.

\begin{tabular}{llll}
\hline & $\begin{array}{l}\text { Koloutsou-Vakakis } \\
(\gamma=0.33)\end{array}$ & $\begin{array}{l}\text { AAO } f(\mathrm{RH}) \text { analysis } \\
(\gamma=0.51)\end{array}$ & $\begin{array}{l}\text { Quinn et al. (2005) } \\
(\gamma=0.67)\end{array}$ \\
\hline $\mathrm{AOD}$ & $1.47\left(R^{2}=0.72\right)$ & $1.36\left(R^{2}=0.72\right)$ & $1.27\left(R^{2}=0.72\right)$ \\
$\mathrm{a}$ & $0.82\left(R^{2}=0.40\right)$ & $0.81\left(R^{2}=0.43\right)$ & $0.80\left(R^{2}=0.43\right)$ \\
$\varpi_{\mathrm{O}}$ & - & - & - \\
$b$ & $0.53\left(R^{2}=0.18\right)$ & $0.56\left(R^{2}=0.11\right)$ & $0.58\left(R^{2}=-0.04\right)$ \\
$g$ & - & - & - \\
$\mathrm{FMF}$ & $0.89\left(R^{2}=0.21\right)$ & $0.96\left(R^{2}=-0.1\right)$ & $1.00\left(R^{2}=-0.4\right)$ \\
\hline
\end{tabular}

at the surface are different (size, amount, composition, etc.) than those measured on the lowest flight level.

Another way to gain insight on whether the inlet is excluding large particles is to compare the submicrometer scattering fraction, $R_{\mathrm{sp}}$, measured on the airplane with that measured at the surface. Figure 13 is a frequency distribution plot using the $R_{\mathrm{sp}}$ calculated for flight segments over Bondville. The frequency histogram was calculated two ways: (a) for all flight segments over Bondville, and (b) for flight segments where the scattering coefficient was $\geq 5 \mathrm{Mm}^{-1}$. Limiting the data to $\geq 5 \mathrm{Mm}^{-1}$ biases the data somewhat toward the lower flight altitudes (about $30 \%$ of the flight segments are excluded), but this plot should closely represent data collected in the mixed layer over Bondville. For the limited case, the most common observation range is $0.90-0.95$. The median of the distribution is 0.88 , with a mean value of 0.86 , which agrees well with the long-term $R_{\mathrm{sp}}$ reported for Bondville of $0.85 \pm 0.09$ (Delene and Ogren, 2002).

Observing similar $R_{\mathrm{sp}}$ values between $\mathrm{AAO}$ and Bondville surface measurements suggests that the aerosol size distribution was similar at the different altitudes. The comparison shown in Fig. 8 however, suggests that there is either less aerosol at the lowest flight altitude or that not all of this aerosol is reaching the nephelometer. Unfortunately, it is not possible to separate these two possibilities with this data set, making difficult to completely rule them out. Thus, we cannot reject the hypothesis that the AAO inlet is excluding larger aerosol particles, but comparison with surface data suggests that this hypothesis can only account for a small portion of the discrepancy between the AERONET AOD and the AAO aircraft calculated AOD.

The effect of the aircraft inlet on the AOD calculated from the AAO measurements can also be investigated using the volume particle size distribution, which AERONET provides over the diameter range $0.1-30 \mu \mathrm{m}$ as one of its inversion products (Dubovik et al., 2000) (size distributions on the aircraft were only measured up to $0.5 \mu \mathrm{m}$ diameter). For this analysis, Mie theory was first used to calculate the AERONET AOD for 4 different values of the refractive index (RI) (real RI $=1.35,1.40,1.45$, or 1.50 ; imaginary $\mathrm{RI}=0.004)$. We chose the RI that provided the best match between the AERONET measured AOD and the Mie calculated

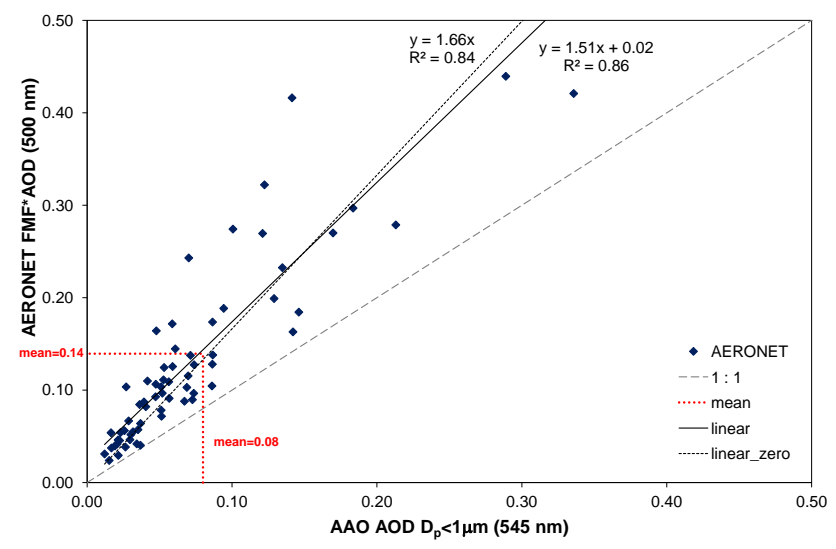

Fig. 11. Comparison of AAO aircraft calculated submicrometer AOD (at $545 \mathrm{~nm}$ ) with AERONET Fine AOD (at $500 \mathrm{~nm}$ ).

AOD. Then, the cumulative AOD values were calculated as a function of particle diameter, and we determined the diameter where the cumulative AERONET AOD matched the AAO measured AOD. Figure 14a illustrates the calculation for a flight where the matchup diameter was $0.5 \mu \mathrm{m}$.

Figure $14 \mathrm{~b}$ provides a summary of the results for all the flights where the AERONET size distribution retrievals were within $+/-2 \mathrm{~h}$ of the end of the AAO flights. The figure shows the size distribution of AOD (the AOD in a particular size bin, dAOD/dlogD) for all AERONET retrievals during this study, with asterisks marking the matchup diameter for each AAO flight, and a box-whisker diagram indicating statistics for the diameter for which the calculated cumulative AOD from the AERONET size distribution matches the AAO AOD. Typically, the AAO AOD matches the cumulative AOD values where the maximum diameter is less than $1 \mu \mathrm{m}$, and usually less than $0.5 \mu \mathrm{m}$. The AERONET size distributions suggest that, if the discrepancy between the AOD measured by AERONET and that calculated from the AAO aircraft measurements is due to particle losses in the AAO inlet system, the aircraft instrumentation is missing a lot of sub-micrometer particles. The comparison with surface data from Bondville (Fig. 12) suggests that this is not the case, unless the observing system at the Bondville surface also has similar losses for sub-micrometer particles. Since it is unlikely that both in-situ systems have such similar losses, this analysis of the effect of the aircraft inlet on the AAO calculated AOD is inconclusive, and we cannot reject the hypothesis that the AAO inlet is excluding larger aerosol particles, although it can only account for a small portion of the discrepancy between the AERONET AOD and the AAO aircraft calculated AOD. 


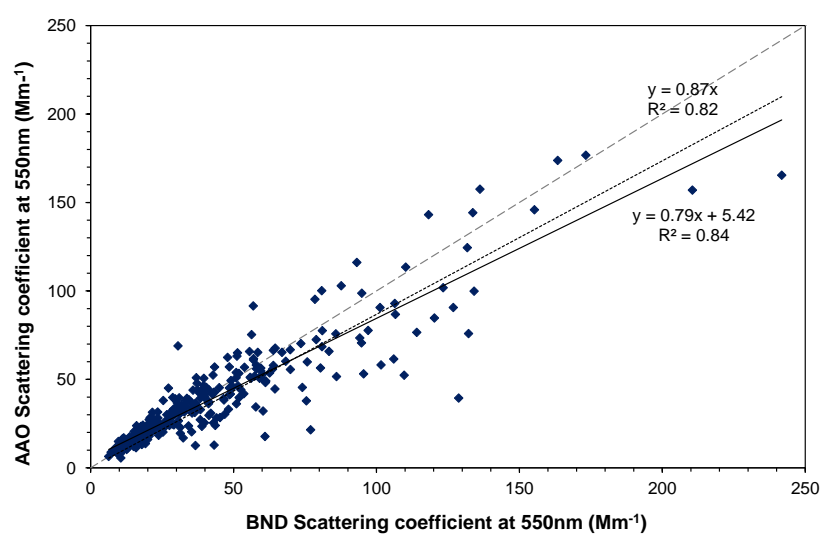

Fig. 12. Comparison of AAO averaged scattering coefficient from the lowest flight level over Bondville with the surface scattering coefficient averaged over the time of each profile.

\subsection{Aerosol below, between or above the profile flight altitudes}

Up to this point only the averaged aerosol optical values measured during the 10 level flight legs have been utilized. The instruments also record 1-s resolution data as the aircraft descends between levels and as it lands after the profile is finished. Here we investigate the possibility of missing aerosol layers below the lowest flight level. We calculated scattering AOD between the surface and 1750 feet $(533 \mathrm{~m})$ in two ways. First we assumed that the scattering measured during the lowest flight level leg was representative of scattering in the entire layer below 1750 feet. Second, we used the 1-s resolution data obtained during the aircraft descent from 1750 feet to landing. The PSAP absorption coefficients were not used because this instrument does not perform well with fast changes in altitude. If there was a consistent pattern of aerosol layers below the lowest flight level the slope relating these two AODs would be greater than 1. Figure 15 shows that while there is a fair amount of scatter in the data $\left(R^{2} \approx 0.70\right)$ the slope $(1.01)$ suggests that the lowest flight level is representative of the $0-1750$ feet layer. However, the comparison shown in Fig. 12 suggests that there is either less aerosol at the lowest flight altitude, compared to the surface, or that not all of this aerosol is getting in to the nephelometer. As previously explained, it is not possible with this data set to separate these two possibilities, making it difficult to completely rule them out. Therefore, there might be a real difference between what is sampled at ground level and what is sampled in the air over the site, since the aerosol at altitude may have been cloud-processed to a greater degree, with relatively higher fractions of hydrophobic (e.g. soot, smoke, dust) particles there, which might not grow as easily when exposed to high RH as the mixed sulfate-rich aerosol at the surface. Thus, the possible presence of unsampled aerosols in the $230 \mathrm{~m}$ below the lowest flight altitude remains

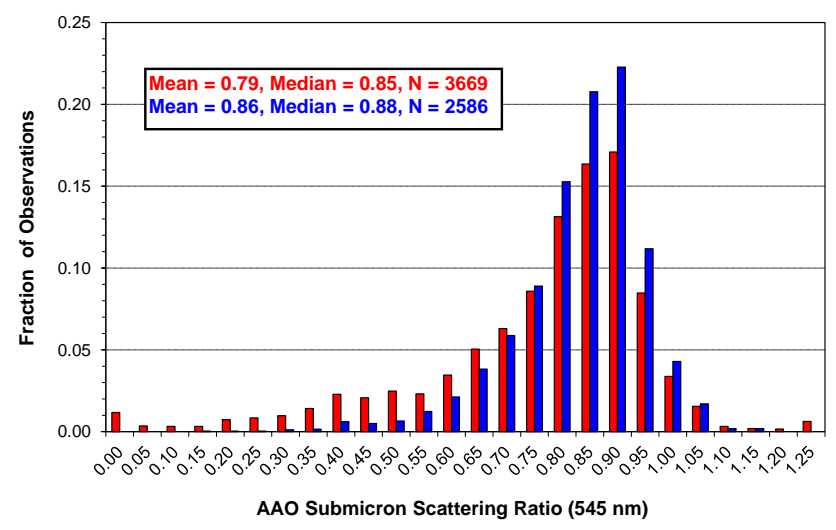

Fig. 13. Frequency distribution of AAO $R_{\mathrm{sp}}$ for all flight segments over Bondville (red) and for flight segments where the scattering coefficient was $\geq 5 \mathrm{Mm}^{-1}$ (blue).

a possible source of discrepancy between the AOD measured by AERONET and the one calculated from the AAO aircraft measurements.

To test the hypothesis that aerosol layers between the fixed sampling levels are missed, an analysis similar to that used to test for missed aerosol layers below the lowest flight level is done. Figure 16 shows the comparison of the scattering AOD calculated from the 1-s resolution data from the aircraft descent between flight altitudes with the scattering AOD calculated from the 10 flight level measurements. The data from the 10 flight level legs has been excluded in the 1-s resolution descent calculation. Again, a slope greater than 1 would indicate that aerosol was missed by only using the 10 flight altitudes, while a slope less than 1 indicates that AOD is not underestimated by just using the averaged flight level measurements to calculate AOD. The comparison shows very good correlation $\left(R^{2} \approx 0.97\right)$, with the scattering optical depth for the descent data being almost the same as that for the fixed flight altitudes. Therefore, we can state that the presence of aerosols layers between the fixed sampling layers is not significant, and that the chosen fixed flight altitudes are representative of the column.

Although the hypothesis of aerosol layers above the highest flight level is unlikely since the aircraft samples up to $4.6 \mathrm{~km}$, the contribution of those layers can be estimated using the CALIPSO (Cloud-Aerosol Lidar and Infrared Pathfinder Satellite Observation) satellite observations, which provide the vertical structure and properties of thin clouds and aerosols over the globe. A detailed evaluation of the CALIPSO data above Bondville is beyond the scope of this paper, but the summary of CALIPSO data reported by Yu et al. (2010) shows that negligible extinction was observed at altitudes of $4.6-10 \mathrm{~km}$ over the Eastern US in 2007. An examination of the CALIPSO "level 3" mean extinction profile for June 2006-October 2008 in a 2 degree latitude by 5 degree longitude grid box, roughly centered on 

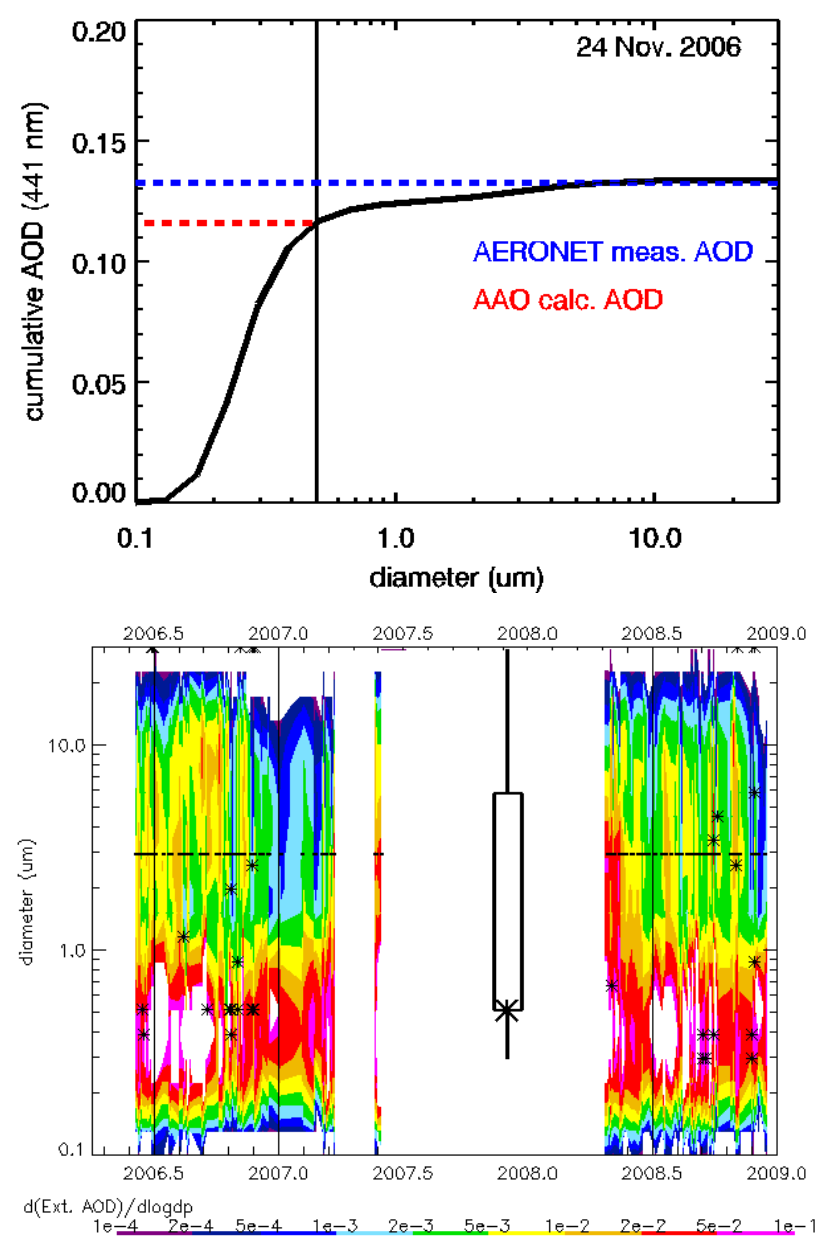

Fig. 14. (a) Cumulative AOD calculated from the AERONET measurements as a function of diameter for one AERONET size distribution retrieval. Vertical line represents the diameter where cumulative AERONET AOD matches AAO AOD; (b) Time series contour plot of AOD size distribution $(\mathrm{dAOD} / \mathrm{d} \log \mathrm{D})$ as a function of diameter. The color contours are based on AERONET volume size distribution retrievals and assumed refractive index as described in text. The asterisks $\left(^{*}\right)$ represent the diameter where the AAO AOD matches the cumulative AOD derived from AERONET size distributions (assuming $\gamma=0.67$ for RH adjustment). The box-whisker diagram indicates statistics for the diameter for which the calculated cumulative AOD from the AERONET size distribution matches the AAO AOD. The ends of the whiskers are the 5th and 95th percentiles, the ends of the box are the 25th and 75th percentiles and the asterisk represents the median value (same as 25 th percentile).

Bondville, also reveals negligible extinction above $4.6 \mathrm{~km}$ (J. Tackett, personal communication, 2012). Finally, Vernier et al. (2011) demonstrate that the zonally-averaged AOD of stratospheric aerosols at $20-30 \mathrm{~km}$ altitude at $20-50^{\circ} \mathrm{N}$ latitude during the study period was less than 0.005 .

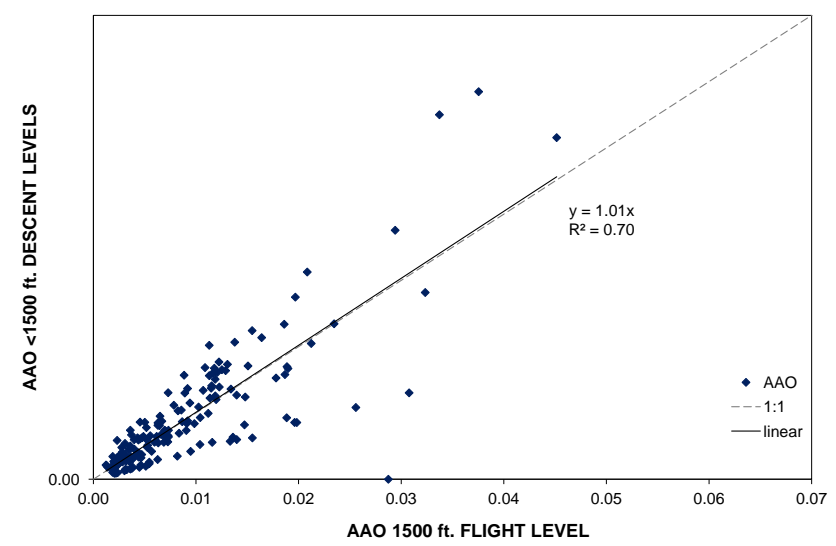

Fig. 15. Comparison of AAO aircraft calculated scattering optical depth adjusted to ambient RH for the levels of the descent data below 1750 feet with AAO scattering optical depth adjusted to ambient RH for the sampling flight level at 1500 feet (at $550 \mathrm{~nm}$ ).

\subsection{Nephelometer truncation correction}

Another possible source of discrepancy between the AOD measured by AERONET and the one calculated from the $\mathrm{AAO}$ aircraft measurements is an incorrect correction of the nephelometer data for truncation effects. The nephelometer truncation error is less than $5 \%$ for submicrometer particles (Anderson and Ogren, 1998), so the main contribution to this error will be from coarse mode particles. These particles only contribute $15 \%$ of the scattering at the surface at Bondville (Delene and Ogren, 2002) and 10-20\% of the scattering measured on the AAO aircraft (Fig. 8). Even if the uncertainty of the truncation correction is a factor of two for supermicrometer particles, the overall uncertainty in the nephelometer truncation correction is only about $30 \%$. Therefore, an incorrect correction of the nephelometer data for truncation effects for supermicrometer particles may be a minor source of discrepancy between the AERONET AOD and the AAO aircraft calculated AOD, but cannot explain the factor of 1.5 average difference.

\subsection{Cloud screening method}

Recent studies have quantified the contribution of tropical cirrus clouds to AERONET AOD measurements (Chew et al., 2011; Huang et al., 2011) as a bias of 0.03-0.05 in AOD (at $500 \mathrm{~nm}$ wavelength) and a shift of the Ångström exponent and fine mode fraction to smaller values (i.e. more large particles). These are clouds that were not removed by the AERONET "level 2.0" screening criteria. While the same criteria were applied to derive the "level 2.0" AOD data at Bondville, supporting lidar measurements are not available to assess whether the findings from the tropics are applicable to the AOD observations at Bondville. If the tropical findings apply to Bondville, cirrus clouds could explain much 


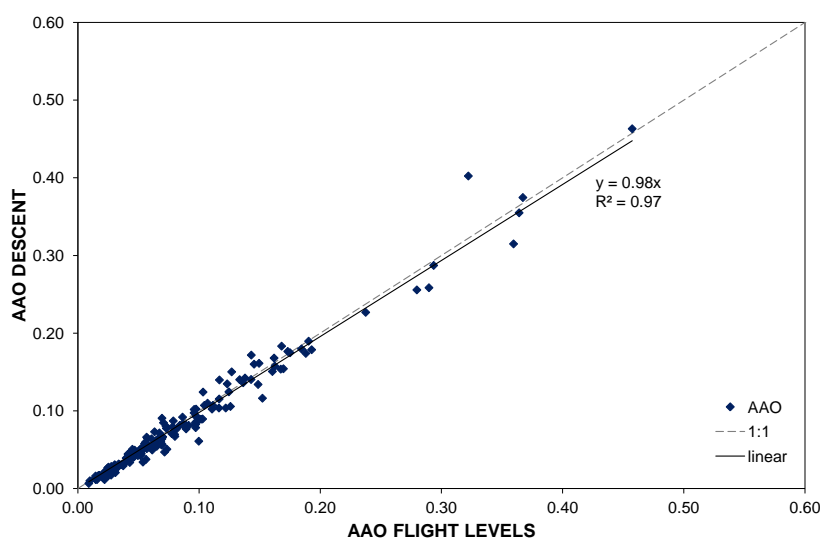

Fig. 16. Comparison of AAO aircraft calculated scattering optical depth adjusted to ambient $\mathrm{RH}$ for all the descent data with AAO scattering optical depth adjusted to ambient RH for the fixed sampling layers (at $550 \mathrm{~nm}$ ).

of the offset of 0.05 observed in the AOD regression analysis (Sect. 3) as well as the observed differences in Ångström exponent and fine mode fraction.

To address the hypothesis of an incorrect AERONET AOD cloud screening method, the AOD calculated from the AAO aircraft measurements has been compared with the AOD measured by NOAA's SURFace RADiation budget (SURFRAD) network (Augustine et al., 2000, 2005). Spectral solar measurements are made at SURFRAD stations with a multifilter rotating shadowband radiometer (MFRSR), and the cloud screening method (Alexandrov et al., 2004) used to remove measurements contaminated by clouds is different from that used by AERONET (Smirnov et al., 2000). Comparison of the AOD measured by SURFRAD's MFRSR (adjusted to $550 \mathrm{~nm}$ by power law interpolation) with that calculated from the AAO aircraft measurements shows approximately the same results as those obtained using the AERONET measurements, with fair correlation $\left(R^{2} \approx 0.80\right.$ for the standard linear regression), and a similar linear regression $(y=1.17 x+0.05)$ (again the consistent offset of $\approx 0.05$ ). The $2 \%$ difference between AERONET and SURFRAD is consistent with the results obtained by Augustine et al. (2007), who showed that Bondville AERONET measurements are nearly $2 \%$ higher than those of SURFRAD. Although SURFRAD uses a different instrument and a different cloud-screening method than AERONET, the comparison with the AAO AOD does not change, so the hypothesis of AERONET cloud screening method as a source of discrepancy is unlikely. However, the possibility still remains that sub-visible cirrus clouds might have been present but not removed by the AERONET cloud screening algorithm.

\subsection{Wavelength adjustment}

We employed the widely-used convention that the wavelength dependence of the aerosol optical depth is best described by a power-law relationship (Ångström, 1929) to adjust the wavelength of the AERONET measurements to $550 \mathrm{~nm}$. To address the hypothesis that the discrepancy between the AOD measured by AERONET and that calculated from the AAO aircraft measurements is due to an incorrect choice of interpolation scheme, we repeated the comparison using a linear interpolation instead. The resulting slope of the linear regression line, forced through the origin, changed by only $3.5 \%$. Consequently, the power law interpolation is not an important source of the discrepancy between the AOD retrieved by AERONET and the one calculated from the AAO aircraft measurements.

\subsection{Temporal variability of the aerosol}

Another possible source of discrepancy between the AOD measured by AERONET and the one calculated from the AAO aircraft measurements is the temporal variability of the aerosol optical properties. The AOD comparisons presented in this paper use AERONET data taken within $+/-2 \mathrm{~h}$ of the end of the AAO flight. Significant temporal variability over a two hour time period could possibly result in a discrepancy between AERONET and AAO AOD, although it would be unusual if such variability resulted in a consistent positive or negative bias. Anderson et al. (2003) quantified how well a measurement made at one point represents the value at another point, in time or space, using the autocorrelation coefficient. For the surface data at Bondville, we calculated the 2-h lag autocorrelation to be 0.92 , which implies the surface measurements are highly correlated over a two hour time period. Thus, it is unlikely that the temporal variability of the aerosol optical properties at Bondville is a source of discrepancy between AERONET AOD and the AAO aircraft calculated AOD.

\subsection{Biases in instrument measurements}

Another possible source of discrepancy between the AOD retrieved by AERONET and the one calculated from the AAO aircraft measurements is bias in the AAO and AERONET measurements. Nephelometer calibration uncertainties introduce an error of $\approx 1 \%$, while the nephelometer truncation error is less than $5 \%$ for submicrometer particles (Anderson and Ogren, 1998). The PSAP may have a potential positive bias due to organic aerosol (Cappa et al., 2008; Lack et al., 2008), but a positive bias is the opposite direction to the observed discrepancy between AAO and AERONET. The Bond et al. (1999) correction attributes about $2 \%$ of the scattering as absorption (Bond et al., 1999) so using too big of a Bond correction goes the same way as the observed AAO/AERONET discrepancy. However, aerosol absorption 
is in general a very small contributor to AOD (absorption accounts for less than $10 \%$ of the scattering at the surface in Bondville) and biases in the absorption data are unlikely to be a significant source of the differences observed. The uncertainty in AOD from the AERONET sun photometer is $\approx 1 \%$ for $\lambda>440 \mathrm{~nm}$ (Holben et al., 1998). Since all the errors in the AAO and AERONET measurements are very low, it is unlikely that they are a source of discrepancy between AERONET AOD and the AAO aircraft calculated AOD.

\subsection{Aerosol intensive properties discrepancies}

Above we have explored multiple hypotheses to try to explain the large discrepancy between AAO and AERONET AOD. Of these, one of the most significant was found to be the method chosen to adjust the AAO measurements to ambient RH. We have not investigated the reasons for the differences observed between AAO and AERONET intensive properties (Ångström exponent, $\varpi_{\mathrm{o}}, g, b$ ) since it is difficult to verify the AERONET retrieval algorithm at a site that is not highly polluted. While adjustment to ambient $\mathrm{RH}$ will affect these comparisons as well (see Table 3), below we suggest some additional possibilities.

1. For the Ångström exponent, the aircraft inlet excludes larger aerosol particles.

2. For the single scattering albedo, (a) error in the AERONET algorithm, (b) an increased uncertainty in AERONET during low AOD measurements, and (c) a possible RH dependence of absorption.

3. For the hemispheric backscatter fraction and the asymmetry parameter, an error in the AERONET algorithm.

4. For the Fine Mode Fraction, (a) an error in the spectral AOD measurements, (b) an error in the AERONET algorithm, and (c) difference between AAO size cut and AERONET identification of fine mode aerosol.

All these hypotheses for the retrievals discrepancies have yet to be explored.

\section{Conclusions}

Aerosol optical properties were measured by NOAA's Airborne Aerosol Observatory over Bondville, Illinois, during more than two years using a light aircraft. Measured properties included total light scattering, backscattering, and absorption, while calculated parameters included aerosol optical depth, Ångström exponent, single-scattering albedo, hemispheric backscatter fraction, asymmetry parameter, and submicrometer mode fraction. The in-situ aircraft measurements adjusted to ambient conditions have been compared with the AERONET measurements and retrievals of the aerosol optical properties. The comparison showed discrepancies between aerosol properties retrieved from AERONET and those retrieved from in-situ aircraft measurements. These discrepancies are smaller for the AOD than for the retrievals $\left(\varpi_{\mathrm{o}}, g, b\right)$.

The comparison of the AOD measured by the AERONET sun photometer with that calculated from the AAO aircraft measurements showed good correlation $\left(R^{2} \approx 0.79\right)$, but the AERONET AOD values were between $27 \%$ and $47 \%$ higher than the calculated AAO AOD. Different hypotheses for the discrepancy between the AOD measured by AERONET and the one calculated from the AAO aircraft measurements have been analyzed. These include an incorrect adjustment of $\sigma_{\mathrm{sp}}$ and $\sigma_{\mathrm{bsp}}$ values to ambient $\mathrm{RH}$ using estimates of hygroscopic growth, the aircraft inlet excluding larger aerosol particles, aerosol layers below, between or above the fixed sampling levels, an incorrect correction of the nephelometer data for angular nonidealities, an incorrect AERONET AOD cloud screening method, an incorrect adjustment of the wavelength of the AERONET sun photometer to $550 \mathrm{~nm}$, the temporal variability of the aerosol optical properties, and the bias in the AAO and AERONET measurements. After evaluating all of these hypotheses, we conclude that the largest portion of the observed AOD discrepancy is probably due to an incorrect adjustment of light scattering to ambient RH; improved measurements of the aerosol hygroscopic growth factor would be needed to confirm this diagnosis. Another part of the discrepancy might come from either less aerosol at the lowest flight altitude, relative to the surface, or that the aircraft inlet excludes larger aerosol particles; however, it was not possible to separate these two possibilities with this data set, making it difficult to completely rule them out. Spaceborne lidar observations indicate a minimal contribution to AOD from aerosol layers above the highest flight level.

Comparison of the derived aerosol properties (Ångström exponent, single scattering albedo, hemispheric backscatter fraction, and asymmetry parameter) calculated from the AERONET measurements with those calculated from the AAO aircraft measurements showed low correlation and significant differences. AAO single scattering albedo could only be compared with a single AERONET retrieval, illustrating the difficulty of verifying the AERONET retrieval algorithm at a site that is not highly polluted. AAO asymmetry parameter and backscatter fraction values showed a wider range than the AERONET retrievals, with the AAOderived values being lower for asymmetry parameter and higher for backscatter fraction. Different hypotheses for the discrepancy between the aerosol properties retrieved from AERONET (Ångström exponent, $\varpi_{\mathrm{o}}, g, b$ ) and the retrieved from the AAO aircraft measurements were suggested but not explored. 
Acknowledgements. This research was funded by the NOAA Climate Program. The collaboration of A. R. Esteve was possible thanks to the fellowship BES-2006-12521 and the project CGL2009-07790 of the Ministry of Science and Innovation (MICINN) of the Spanish Government. The authors would like to thank Alexander Smirnov for his help with the AERONET data; John Augustine for the MFRSR data; Jenny Hand for the IMPROVE data; Jason Tackett for examining the CALIPSO data above the aircraft flight altitudes; and the pilots, crew and support personnel of Greenwood Aviation.

Edited by: E. Gerasopoulos

\section{References}

Alexandrov, M. D., Marshak, A., Cairns, B., Lacis, A. A., and Carlson, B. E.: Automated cloud screening algorithm for MFRSR data, Geophys. Res. Lett., 31, L04118, doi:10.1029/2003GL019105, 2004.

Anderson, T. L. and Ogren, J. A.: Determining Aerosol Radiative Properties Using the TSI 3563 Integrating Nephelometer, Aerosol. Sci. Tech., 29, 57-69, 1998.

Anderson, T. L., Covert, D. S., Wheeler, J. D., Harris, J. M., Perry, K. D., Trost, B. E., Jaffe, D. J., and Ogren, J. A.: Aerosol back scatter fraction and single scattering albedo: Measured values and uncertainties at a coastal station in the Pacific Northwest, J. Geophys. Res., 104, 26793-26807, 1999.

Anderson, T. L., Charlson, R. J., Winker, D. M., Ogren, J. A., and Holmén, K.: Mesoscale Variations of Tropospheric Aerosols, J. Atmos. Sci., 60, 119-136, 2003.

Andrews, E., Sheridan, P. J., Ogren, J. A., and Ferrare, R.: In Situ Aerosol Profiles over the Southern Great Plains CART site, Part I: Aerosol Optical Properties, J. Geophys. Res., 109, D06208, doi:10.1029/2003JD004025, 2004.

Andrews, E., Sheridan, P. J., Fiebig, M., McComiskey, A., Ogren, J. A., Arnott, P., Covert, D., Elleman, R., Gasparini, R., Collins, D., Jonsson, H., Schmid, B., and Wang, J.: Comparison of methods for deriving aerosol asymmetry parameter, J. Geophys. Res., 111, D05S04, doi:10.1029/2004JD005734, 2006.

Ångström, A.: On the Atmospheric Transmission of Sun Radiation and on Dust in the Air, Geogr. Ann., 11, 156-166, 1929.

Atkinson, D. B., Massoli, P., O’Neill, N. T., Quinn, P. K., Brooks, S. D., and Lefer, B.: Comparison of in situ and columnar aerosol spectral measurements during TexAQS-GoMACCS 2006: testing parameterizations for estimating aerosol fine mode properties, Atmos. Chem. Phys., 10, 51-61, doi:10.5194/acp-10-512010, 2010.

Augustine, J. A., DeLuisi, J. J., and Long, C. N.: SURFRAD A national surface radiation budget network for atmospheric research, B. Am. Meteorol. Soc., 81, 2341-2357, 2000.

Augustine, J. A., Hodges, G. B., Cornwall, C. R., Michalsky, J. J., and Medina, C. I.: An update on SURFRAD - The GCOS surface radiation budget network for the continental United States, J. Atmos. Ocean. Tech., 22, 1460-1472, 2005.

Augustine, J. A., Hodges, G. B., Dutton, E. G., Michalsky, J. J., and Cornwall, C. R.: An aerosol optical depth climatology for NOAA's national surface radiation budget network (SURFRAD), J. Geophys. Res., 113, D11204, doi:10.1029/2007JD009504, 2007.
Bergin, M. H., Ogren, J. A., Schwartz, S. E., and McInnes, L. M.: Evaporation of ammonium nitrate aerosol in a heated nephelometer: Implications for field measurements, Environ. Sci. Technol., 31, 2878-2883, 1997.

Bergstrom, R. W., Pilewskie, P., Schmid, B., and Russell, P. B.: Estimates of the spectral aerosol single scattering albedo and aerosol radiative effects during SAFARI 2000, J. Geophys. Res., 108, 8474, doi:10.1029/2002JD002435, 2003.

Bond, T. C., Anderson, T. L., and Campbell, D.: Calibration and Intercomparison of Filter-Based Measurements of Visible Light Absorption by Aerosols, Aerosol. Sci. Tech., 30, 582-600, 1999.

Cappa, C. D., Lack, D. A., Burkholder, J. B., and Ravishankara, A. R.: Bias in Filter-Based Aerosol Light Absorption Measurements Due to Organic Aerosol Loading: Evidence from Laboratory Measurements, Aerosol. Sci. Tech., 42, 1022-1032, 2008.

Chand, D., Guyon, P., Artaxo, P., Schmid, O., Frank, G. P., Rizzo, L. V., Mayol-Bracero, O. L., Gatti, L. V., and Andreae, M. O.: Optical and physical properties of aerosols in the boundary layer and free troposphere over the Amazon Basin during the biomass burning season, Atmos. Chem. Phys., 6, 2911-2925, doi:10.5194/acp-6-2911-2006, 2006.

Charlson, R. J., Langer, J., Rodhe, H., Leovy, C. B., and Warren, S. G.: Perturbation of the northern hemispheric radiative balance by backscattering from anthropogenic sulfate aerosol, Tellus, 43, 152-163, 1991.

Charlson, R. J., Schwartz, S. E., Hales, J. M., Cess, R. D., Coakley Jr., J. A., Hansen, J. E., and Hofmann, D. J.: Climate forcing by anthropogenic aerosol, Science, 255, 423-430, 1992.

Chew, B. N., Campbell, J. R., Reid, J. S., Giles, D. M., Welton, E. J., Salinas, S. V., and Liew, S. C.: Tropical cirrus cloud contamination in sun photometer data, Atmos. Environ., 45, 6724-6731, 2011.

Covert, D. S., Charlson, R. J., and Ahlquist, N. C.: A study of the relationship of chemical composition and humidity to light scattering by aerosols, J. Appl. Meteorol., 11, 968-976, 1972.

Delene, D. J. and Ogren, J. A.: Variability of aerosol optical properties at four North American surface monitoring sites, J. Atmos. Sci., 59, 1135-1150, 2002.

Dubovik, O. and King, M. D.: A flexible inversion algorithm for retrieval of aerosol optical properties from Sun and sky radiance measurements, J. Geophys. Res., 105, 20673-20696, 2000.

Dubovik, O., Smirnov, A., Holben, B. N., King, M. D., Kaufman, Y. J., Eck, T. F., and Slutsker, I.: Accuracy assessments of aerosol optical properties retrieved from Aerosol Robotic Network (AERONET) Sun and sky radiance measurements, J. Geophys. Res., 105, 9791-9806, 2000.

Gassó, S., Hegg, D. A., Covert, D. S., Collins, D., Noone, K. J., Öström, E., Schmid, B., Russell, P. B., Livingston, J. M., Durkee, P. A., and Johsson, H.: Influence of humidity on the aerosol scattering coefficient and its effect on the upwelling radiance during ACE-2, Tellus B, 52, 546-567, 2000.

Hand, J. L., Copeland, S. A., Day, D. E., Dillner, A. M., Indresand, H., Malm, W. C., McDade, C. E., Moore, C. T., Pitchford, M. L., Schichtel, B. A., and Watson, J. G.: IMPROVE, Spatial and Seasonal Patterns and Temporal Variability of Haze and its Constituents in the United States, ISSN 0737-5352-0787, available at: http://vista.cira.colostate.edu/improve/Publications/Reports/ 2011/2011.htm, 2011.

Hartley, W. S., Hobbs, P. V., Ross, J. L., Russell, P. B., and Liv- 
ingston, J. M.: Properties of aerosols aloft relevant to direct radiative forcing off the mid-Atlantic coast of the United States, J. Geophys. Res., 105, 9859-9885, 2000.

Haywood, J. M. and Shine, K. P.: The effect of anthropogenic sulfate and soot aerosol on the clear sky planetary radiation budget, Geophys. Res. Lett., 22, 603-606, 1995.

Haywood, J. M., Francis, P. N., Glew, M. D., Dubovik, O., and Holben, B. N.: Comparison of aerosol size distributions, radiative properties and optical depths determined by aircraft observations and sunphotometers during SAFARI 2000, J. Geophys. Res., 108, 8473, doi:10.1029/2002JD002250, 2003.

Haywood, J., Bush, M., Abel, S., Claxton, B., Coe, H., Crosier, J., Harrison, M., Macpherson, B., Naylor, M., and Osborne, S.: Prediction of visibility and aerosol within the operational Met Office United Model. II: Validation of model performance using observational data, Q. J. Roy. Meteor. Soc., 134, 1817-1832, doi:10.1002/qj.275, 2008.

Hegg, D. A., Covert, D. S., Rood, M. J., and Hobbs, P. V.: Measurements of aerosol optical properties in marine air, J. Geophys. Res., 101, 12893-12903, 1996a.

Hegg, D. A., Livingston, J., Hobbs, P. V., Nance, J. D., and Rangno, A. L.: Aerosol measurements in the Arctic relevant to direct and indirect radiative forcing, J. Geophys. Res., 101, 23349-23363, 1996b.

Holben, B. N., Eck, T. F., Slutsker, I., Tanré, D., Buis, J. P., Setzer, A., Vermote, E., Reagan, J. A., Kaufman, Y. J., Nakajima, T., Lavenu, F., Jankowiak, I., and Smirnov, A.: AERONET A Federated Instrument Network and Data Archive for Aerosol Characterization, Remote. Sens. Environ., 66, 1-16, 1998.

Holben, B. N., Tanré, D., Smirnov, A., Eck, T. F., Slutsker, I., Abuhassan, N., Newcomb, W. W., Schafer, J. S., Chatenet, B., Lavenu, F., Kaufman, Y. J., Vande Castle, J., Setzer, A., Markham, B., Clark, D., Frouin, R., Halthore, R., Karneli, A., O'Neill, N. T., Pietras, C., Pinker, R. T., Voss, K., and Zibordi, G.: An emerging ground-based aerosol climatology: Aerosol Optical Depth from AERONET, J. Geophys. Res., 106, 1206712097, 2001.

Huang, J., Hsu, N. C., Tsay, S.-C., Jeong, M.-J., Holben, B. N., Berkoff, T. A., and Welton, E. J.: Susceptibility of aerosol optical thickness retrievals to thin cirrus contamination during the BASE-ASIA campaign, J. Geophys. Res., 116, D08214, doi:10.1029/2010JD014910, 2011.

Intergovernmental Panel on Climate Change (IPCC): Climate Change 2007: The Physical Science Basis, Contribution of Working Group I to the Fourth Assessment Report of the Intergovernmental Panel on Climate Change, Cambridge, UK and New York, NY, USA, 2007.

Johnson, B. T., Christopher, S., Haywood, J. M., Osborne, S. R., McFarlanec, S., Hsu, C., Salustro, C., and Kahn, R.: Measurements of aerosol properties from aircraft, satellite and groundbased remote sensing: A case-study from the Dust and Biomassburning Experiment (DABEX), Q. J. Roy. Meteor. Soc., 135, 922-934, 2009.

Kaufman, Y. J., Koren, I., Remer, L. A., Rosenfeld, D., and Rudich, Y.: The effect of smoke, dust, and pollution aerosol on shallow cloud development over the Atlantic Ocean, P. Natl. Acad. Sci. USA, 102, 11207-11212, 2005.

Kiehl, J. T. and Briegleb, B. P.: The relative roles of sulphate aerosols and greenhouse gases in climate forcing, Science, 260,
311-314, 1993.

Koloutsou-Vakakis, S., Carrico, C. M., Kus, P., Rood, M. J., Li, Z., Shrestha, R., Ogren, J. A., Chow, J. C., and Watson, J. G.: Aerosol properties at a midlatitude Northern Hemisphere continental site, J. Geophys. Res., 106, 3019-3032, 2001.

Kotchenruther, R. A., Hobbs, P. V., and Hegg, D. A.: Humidification factors for atmospheric aerosols off the mid-Atlantic coast of the United States, J. Geophys. Res., 104, 2239-2251, 1999.

Lack, D. A., Cappa, C. D., Covert, D. S., Baynard, T., Massoli, P., Sierau, B., Bates, T. S., Quinn, P. K., Lovejoy, E. R., and Ravishankara, A. R.: Bias in Filter-Based Aerosol Light Absorption Measurements Due to Organic Aerosol Loading: Evidence from Ambient Measurements, Aerosol. Sci. Tech., 42, 1033-1041, 2008.

Leahy, L. V., Anderson, T. L., Eck, T. F., and Bergstrom, R. W.: A synthesis of single scattering albedo of biomass burning aerosol over southern Africa during SAFARI 2000, Geophys. Res. Lett., 34, L12814, doi:10.1029/2007GL029697, 2007.

McNaughton, C. S., Clarke, A. D., Howell, S. G., Pinkerton, M., Anderson, B., Thornhill, L., Hudgins, C., Winstead, E., Dibb, J. E., Scheuer, E., and Maring, H.: Results from the DC-8 Inlet Characterization Experiment (DICE): Airborne Versus Surface Sampling of Mineral Dust and Sea Salt Aerosols, Aerosol. Sci. Tech., 41, 136-159, 2007.

O’Neill, N. T., Eck, T. F., Holben, B. N., Smimov, A., Dubovik, O., and Royer, A.: Bimodal size distribution influences on the variation of Angstrom derivatives in spectral and optical depth space, J. Geophys. Res., 106, 9787-9806, 2001.

Öström, E. and Noone, K. J.: Vertical profiles of aerosol scattering and absorption measured in situ during the North Atlantic Aerosol Characterization Experiment, Tellus B, 52, 526-545, 2000.

Ogren, J. A.: Comment on "Calibration and Intercomparison of Filter-Based Measurements of Visible Light Absorption by Aerosols", Aerosol. Sci. Tech., 44, 589-591, doi:10.1080/02786826.2010.482111, 2010.

Osborne, S. R. and Haywood, J. M.: Aircraft observations of the microphysical and optical properties of major aerosol species, Atmos. Res., 73, 173-201, 2005.

Osborne, S. R., Johnson, B. T., Haywood, J. M., Baran, A. J., Harrison, M. A. J., and McConnell, C. L.: Physical and optical properties of mineral dust aerosol during the Dust and Biomass-burning Experiment, J. Geophys. Res., 113, D00C03, doi:10.1029/2007JD009551, 2008.

Quinn, P. K., Bates, T. S., Baynard, T., Clarke, A. D., Onasch, T. B., Wang, W., Rood, M. J., Andrews, E., Allan, J., Carrico, C. M., Coffman, D., and Worsnop, D.: Impact of particulate organic matter on the relative humidity dependence of light scattering: A simplified parameterization, Geophys. Res. Lett., 32, L22809, doi:10.1029/2005GL024322, 2005.

Ramanathan, V., Crutzen, P. J., Lelieveld, J., Mitra, A. P., Althausen, D., Anderson, J., Andreae, M. O., Cantrell, W., Cass, G. R., Chung, C. E., Clarke, A. D., Coakley, J. A., Collins, W. D., Conant, W. C., Dulac, F., Heintzenberg, J., Heymsfield, A. J., Holben, B., Howell, S., Hudson, J., Jayaraman, A., Kiehl, J. T., Krishnamurti, T. N., Lubin, D., McFarquhar, G., Novakov, T., Ogren, J. A., Podgorny, I. A., Prather, K., Priestley, K., Prospero, J. M., Quinn, P. K., Rajeev, K., Rasch, P., Rupert, S., Sadourny, R., Satheesh, S. K., Shaw, G. E., Sheridan, P., and Valero, F. P. 
J.: The Indian Ocean Experiment: An Integrated Assessment of the Climate Forcing and Effects of the Great Indo-Asian Haze, J. Geophys. Res.-Atmos., 106, 28371-28399, 2001.

Reid, J. S., Jonsson, H. H., Maring, H. B., Smirnov, A., Savoie, D. L., Cliff, S. S., Reid, E. A., Meier, M. M., Dubovik, O., and Tsay, S. C.: Comparison of size and morphological measurements of coarse mode dust particles from Africa, J. Geophys. Res., 108, 8593, doi:10.1029/2002JD002485, 2003.

Remer, L. A., Gasso, S., Hegg, D. A., Kaufman, Y. J., and Holben, B. N.: Urban/industrial aerosol: Ground-based Sun/sky radiometer and airborne in situ measurements, J. Geophys. Res., 102, 16849-16859, 1997.

Russell, P. B. and Heintzenberg, J.: An overview of the ACE-2 clear sky column closure experiment (CLEARCOLUMN), Tellus B, 52, 463-483, 2000.

Schafer, J. S., Eck, T. F., Holben, B. N., Artaxo, P., and Duarte, A. F.: Characterization of the optical properties of atmospheric aerosols in Amazônia from long-term AERONET monitoring (1993-1995 and 1999-2006), J. Geophys. Res., 113, D04204, doi:10.1029/2007JD009319, 2008.

Schmid, B., Livingston, J. M., Russell, P. B., Durkee, P. A., Jonsson, H. H., Collins, D. R., Flagan, R. C., Seinfeld, J. H., Gassó, S., Hegg, D. A., Öström, E., Noone, K. J., Welton, E. J., Voss, K. J., Gordon, H. R., Formenti, P., and Andreae, M. O.: Clear-sky closure studies of lower tropospheric aerosol and water vapor during ACE-2 using sunphotometer, airborne in-situ, space-borne and ground-based measurements, Tellus B, 52, 568-593, 2000.

Schmid, B., Flynn, C. J., Newsom, R. K., Turner, D. D., Ferrare, R. A., Clayton, M. F., Andrews, E., Ogren, J. A., Johnson, R. R., Russell, P. B., Gore, W. J., and Dominguez, R.: Validation of aerosol extinction and water vapor profiles from routine Atmospheric Radiation Measurement Climate Research Facility measurements, J. Geophys. Res., 114, D22207, doi:10.1029/2009JD012682, 2009.

Sheridan, P. J. and Ogren, J. A.: Observations of the vertical and regional variability of aerosol optical properties over central and eastern North America, J. Geophys. Res., 104, 16793-16805, 1999.
Sheridan, P. J., Jefferson, A., and Ogren, J. A.: Spatial variability of submicrometer aerosol radiative properties over the Indian Ocean during INDOEX, J. Geophys. Res., 107, 8011, doi:10.1029/2000JD000166, 2002.

Smirnov, A., Holben, B. N., Eck, T. F., Dubovik, O., and Slutsker, I.: Cloud screening and quality control algorithms for the AERONET data base, Remote. Sens. Environ., 73, 337-349, 2000.

Smirnov, A., Holben, B. N., Dubovik, O., Frouin, R., Eck, T. F., and Slutsker, I.: Maritime component in aerosol optical models derived from Aerosol Robotic Network data, J. Geophys. Res., 108, 4033, doi:10.1029/2002JD002701, 2003.

Taubman, B. F., Hains, J. C., Thompson, A. M., Marufu, L. T., Doddridge, B. G., Stehr, J. W., Piety, C. A., and Dickerson, R. R.: Aircraft vertical profiles of trace gas and aerosol pollution over the mid-Atlantic United States: Statistics and meteorological cluster analysis, J. Geophys. Res., 111, D10S07, doi:10.1029/2005JD006196, 2006.

VanCuren, R. A.: Asian aerosols in North America: Extracting the chemical composition and mass concentration of the Asian continental aerosol plume from long-term aerosol records in the western United States, J. Geophys. Res., 108, 4623, doi:10.1029/2003JD003459, 2003.

Vernier, J.-P., Thomason, L. W., Pommereau, J.-P., Bourassa, A., Pelon, J., Garnier, A., Hauchecorne, A., Blanot, L., Trepte, C., Degenstein, D., and Vargas, F.: Major influence of tropical volcanic eruptions on the stratospheric aerosol layer during the last decade, Geophys. Res. Lett., 38, L12807, doi:10.1029/2011GL047563, 2011

Yu, H., Chin, M., Winker, D. M., Omar, A. H., Liu, Z., Kittaka, C., and Diehl, T.: Global view of aerosol vertical distributions from CALIPSO lidar measurements and GOCART simulations: Regional and seasonal variations, J. Geophys. Res., 115, D00H30, doi:10.1029/2009JD013364, 2010. 